\title{
Pre-late Weichselian podzol soil, permafrost features and lithostratigraphy at Penttilänkangas, western Finland
}

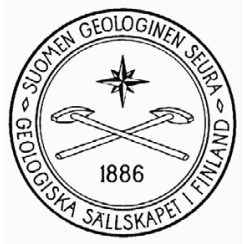

\author{
ReIjo PitKäRANTA \\ Sito Oy, Tietäjäntie 14, FI-02130 Espoo, Finland
}

\begin{abstract}
The ridge-shaped Penttilänkangas accumulation in western Finland is glaciofluvial in origin: probably an ice-marginal subaquatic fan, reworked and covered with younger deep water, littoral, eolian and glacial sediments. Two cycles of glacial melting and land emergence to littoral and subaerial conditions can be distinguished at Penttilänkangas, separated by one glacial advance. Special attention is paid to a fairly well preserved buried podzol soil profile and to permafrost features. The podzol soil is interpreted as having developed in littoral sand and subsequently covered with eolian sand and till. The permafrost features are observable in all the sediments below the covering till, indicating prolonged periglacial ice-free conditions after the soil formation and before the latest glacial advance. The physical properties (content of $<0.0625 \mathrm{~mm}$ fraction, magnetic susceptibility, colour, dry bulk density and LOI) of the buried podzol soil profile are compared to the Holocene podzol soil with similar parent material in the same area. These properties, as well as the identified microfossils and cell tissue, imply that the paleosol probably developed over a longer period and/or in similar or warmer and moister conditions than the Holocene soil. The podzolisation possibly initiated in the Eemian Stage (MIS 5e), and according to the OSL datings, it ceased in the beginning of the Middle Weichselian Substage (MIS 4). After that, ice-free permafrost conditions prevailed for several thousand years before the Weichselian ice-sheet advanced to western Finland around $65 \mathrm{ka}$ at the earliest.
\end{abstract}

Key words: glaciofluvial features, paleosols, podzols, permafrost, lithostratigraphy, physical properties, Pleistocene, Weichselian, Eemian, Penttilänkangas, Isojoki, Finland

* Corresponding author email: reijo.pitkaranta@sito.fi

\section{Introduction}

Paleosols represent ancient ground surfaces. They have developed during different environmental settings from those of the modern conditions: the soil forming process was interrupted due to a climatic change or the soil has been buried in later geological processes (see Ruellan, 1971; Catt, 1990; Reuter, 2000). Paleosols are by definition indicators of past environmental conditions, and they are also valuable lithostratigraphical marker horizons. In a sense, they are trace fossils of ecosystems (Retallack, 1986).

Excluding buried Holocene soil profiles in reactivated aeolian dune fields, observed especially in arctic areas (e.g. Seppälä, 1995; Kotilainen, 2004), paleosols are relatively rare in Fennoscandia (see Kujansuu, 1992; Olsen, 1998). However, buried (fossil) podzol soil profiles have been observed at several plac- 
es in southern Ostrobothnia, western Finland. Earlier reported sites are (see locations in Fig. 1) Kärjenkoski, Risåsen, Harrinkangas, Norinkylä, Haapalankangas, Porokangas, Horonkylä, Uuro and Paulajuurakko (Niemelä \& Tynni, 1979; Donner, 1988; Gibbard et al., 1989; Niemelä \& Jungner, 1991; Kujansuu et al., 1991; Kujansuu, 1992; Hütt et al., 1993; Pitkäranta, 2009). The fossil soils at Kärjenkoski, Risåsen, Norinkylä and Haapalankangas have been dated with optically stimulated luminescence (OSL) and thermoluminescence (TL) methods (Niemelä \& Jungner, 1991; Hütt et al., 1993). The ages of materials underlying the paleosols vary between 100 and $163 \mathrm{ka}$, and of those overlying the paleosols between 76 and $155 \mathrm{ka}$. Hence, the paleosols are considered as having developed in the Eemian Interglacial or in the Early Weichselian temperate ice-free periods.

Like paleosols, also permafrost features are rare in Finland. This is because most of the Finnish territory was either under ice or water at the time when periglacial conditions prevailed in Finland in the Late Weichselian. Signs of Late Weichselian and Holocene permafrost are found only sporadically in elevated ar-

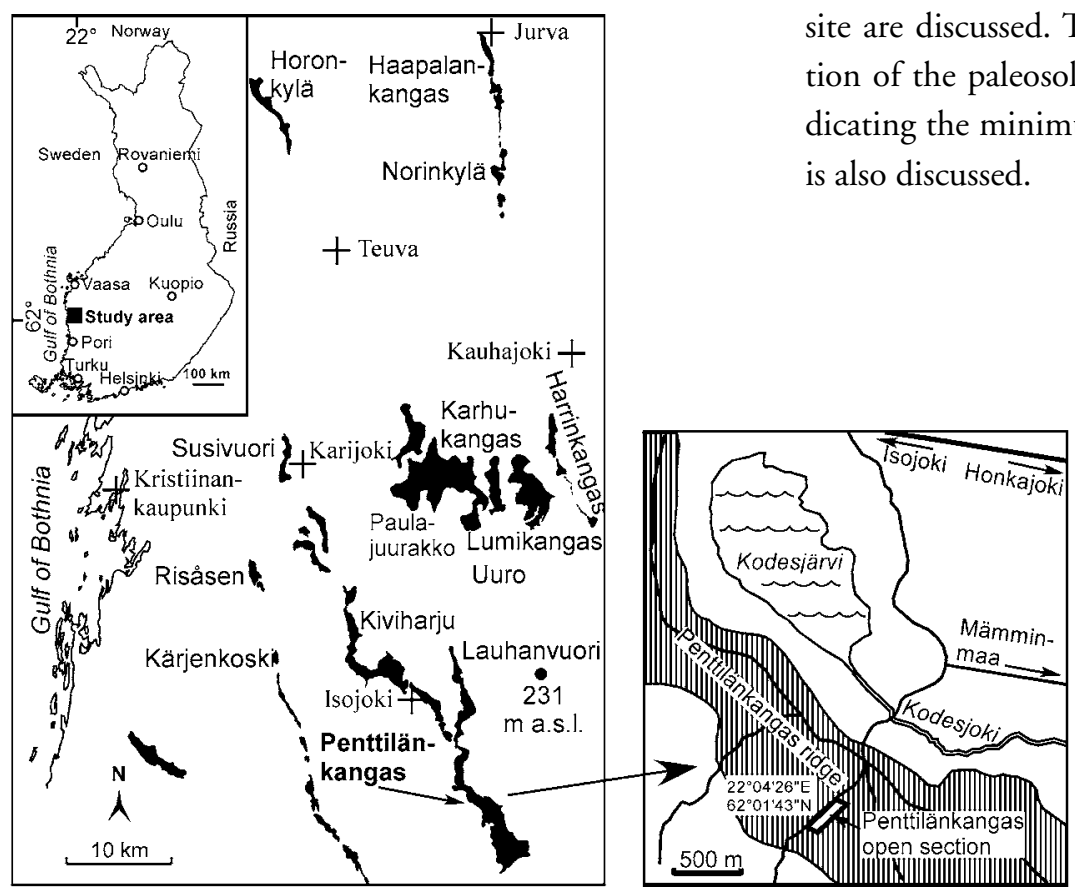
only sporadically in elevated ar-

eas outside the Salpausselkä II end moraines in southern Finland and in northernmost Lapland (see a review in Kejonen, 1997). In addition, permafrost features have abundantly been found in the Suupohja region in western Finland, where they are buried beneath till, and, hence, are interpreted as originating before the latest Weichselian glaciation (Gibbard et al., 1989; Kujansuu, 1992; Pitkäranta, 2009). As a whole, permafrost features occur only sporadically in Scandinavia (Svensson, 1988).

Permafrost features and paleosols are good marker horizons in lithostratigraphy and chronostratigraphy. They indicate prolonged subaerial conditions, which information can be used for separating lithologically similar sedimentary units from each other. Probably their most informative value is that they contain valuable information of past environmental conditions.

In this paper, lithostratigraphy of the Penttilänkangas deposit is presented, emphasizing the stratigraphic significance of the paleosol and the permafrost features. Signs of permafrost are found at Penttilänkangas and at several localities along the same esker-like ridge. Physical characteristics of the paleosol are compared to the Holocene podzol soil in the same area. Two new OSL dates are presented, and the age of the deposits and paleoenvironmental conditions at the site are discussed. The time required for the formation of the paleosol and the permafrost features, induration of the ice-free stage, 


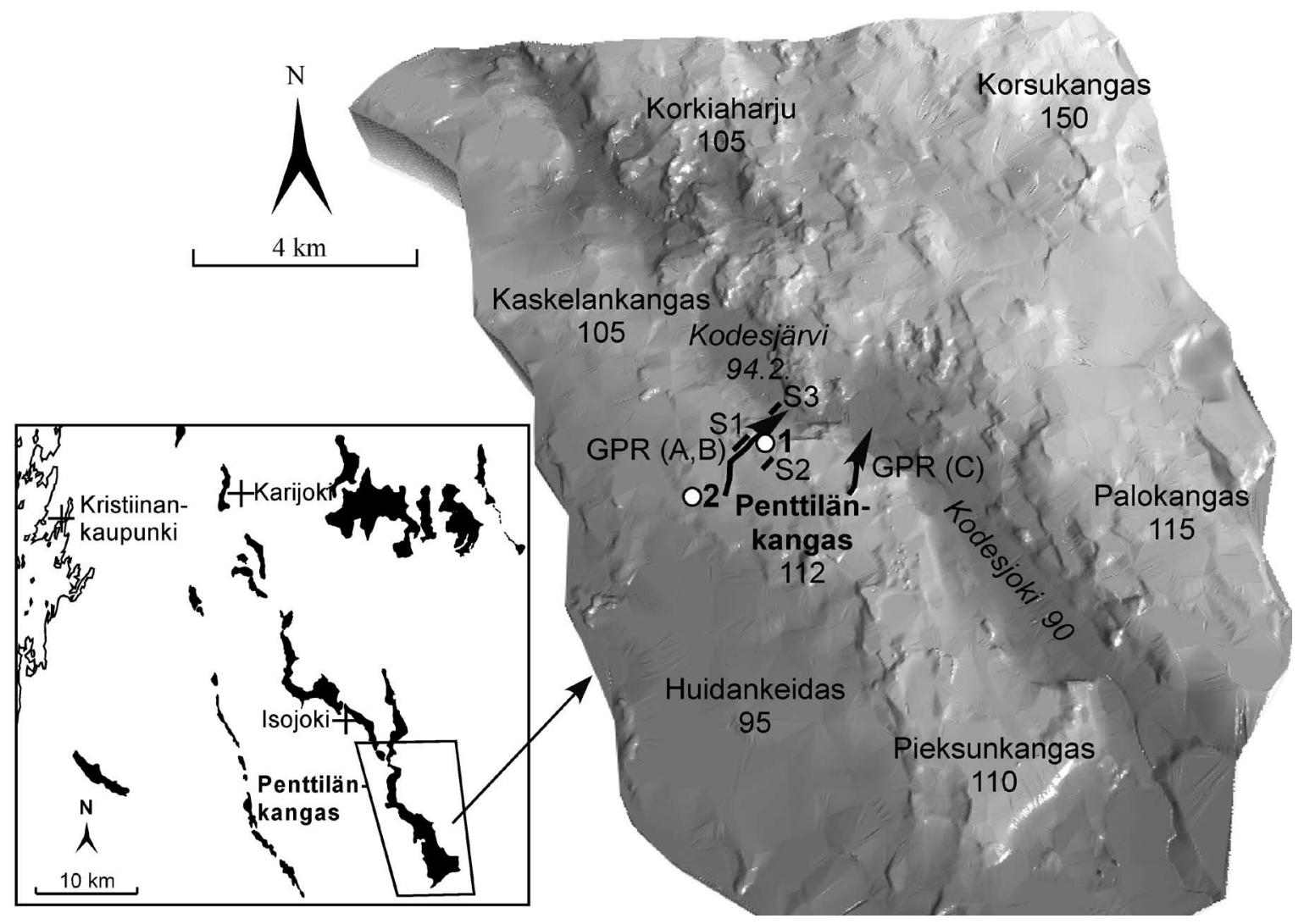

Fig. 2. The surface relief image of the Penttilänkangas accumulation and its surroundings. The buried podzol soil (dot I indicating the location) is compared to the Holocene podzol soil (dot 2) in this study (see Fig. 9). Locations of the GPR images, presented in Fig. 3, are indicated as arrows (arrow indicating the direction of the measurement). Also the seismic lines are indicated (SI-S3). The numbers refer to terrain elevations in metres above sea level. Darker areas show low-lying terrains.

\section{General description of the area with present climatic conditions}

Penttilänkangas $\left(22^{\circ} 04^{\prime} 26^{\prime \prime} \mathrm{E}, 62^{\circ} 01^{\prime} 43^{\prime \prime N}\right)$ is part of a roughly $35 \mathrm{~km}$ long, NW-SE trending sinuous ridge, built up of sand and gravel, and covered at many places by till. It is situated in the Suupohja region, in the southern part of Ostrobothnia, western Finland, where till-covered sorted deposits are common (see e.g. Niemelä, 1978; Niemelä \& Tynni, 1979; Donner, 1988, 1995; Gibbard et al., 1989; Saarnisto \& Salonen, 1995; Pitkäranta, 2005, 2008; Fig. 1). Because comparison between fossil and Holocene podzol soils is made, present environmental settings and climatic conditions are also described.
The highest part of the fairly flat-shaped Penttilänkangas ridge is 112 metres above sea level. The slope of the northeastern flank is ca. $2.2^{\circ}$, and there is a vertical drop of about 17 metres from the top of the hill to the cultivated terrain with fine-grained sediments to the east of the hill. The average slope of the southwestern flank is $1.2^{\circ}$. Here, the terrain rises $7 \mathrm{~m}$ above the peaty and forested bedrock areas, which are draped by a thin till layer. The Kodesjoki river valley follows the Penttilänkangas ridge (Fig. 2).

The bedrock around Penttilänkangas is predominantly granite, granodiorite and tonalite; small occurrences of felsic and intermediate volcanites and metavulcanites are also present (Korsman et al., 1997). Bedrock outcrops are relatively common on the west- 
ern and southwestern side of Penttilänkangas, but rare on the eastern and northeastern side.

According to Alalammi (1987), the present climatic conditions in the study area are as follows: mean annual temperature $+4^{\circ} \mathrm{C}$, with a maximum value of about $29^{\circ} \mathrm{C}$ and minimum values of $-30--26^{\circ} \mathrm{C}$; duration of thermal summer $\left(>10^{\circ} \mathrm{C}\right) \quad 110-115$ days and thermal winter $\left(<0{ }^{\circ} \mathrm{C}\right) 135-140$ days; temperature sum of the thermal summer 400-450 degrees and the mean frost sum between October and April 800-900; maximum soil frost penetration in till at sites cleared of snow 130-140 cm; annual precipitation $650-700 \mathrm{~mm}$, from which the proportion of snow is about $250 \mathrm{~mm}$. The modern forest at the site is Calluna type (CT) after the forest type classification of Cajander (1949).

\section{Field work and analyses}

A shaded relief image (Fig. 2), generated from digitized contour maps, was utilised to outline the extent and shape of the studied ridge. Sedimentological logging was carried out at the open section at Penttilänkangas. In addition, observations of five other gravel pits along the same ridge are referred to, although detailed descriptions of them are not presented here. The logs include fabric ( -50 clasts/unit) and clast lithology analyses (150-200 clasts) from diamictons and gravels, as well as paleocurrent measurements from stratified sands and gravels. Particle sizes were estimated partly visually in the field, and several samples were checked with dry and wet sieving. Fine fractions $(<0.0625 \mathrm{~mm})$ of the soil samples and the material extracted in the wet sieving were analysed with a Coulter LS200, which measures particle sizes based on laser diffraction.

Ground-penetrating radar (GPR) (e.g. Davis \& Annan, 1989; Neal, 2004) was utilised to investigate stratigraphy and architecture of the accumulation, as well as, the depth of bedrock (Fig. 3). Altogether 9 $\mathrm{km}$ of GPR lines were made at Penttilänkangas and in the surrounding area. Both Geophysical Survey System Inc's SIR-10 with a $100 \mathrm{MHz}$ antenna and MalàGeoScience's RAMAC/GPR with 50 and $100 \mathrm{MHz}$ antennas were used. Four refraction seismic soundings (e.g. Sjögren, 1984; Palmer, 1986) were carried out (110 $\mathrm{m}$ and $55 \mathrm{~m}$ geophone spreads) to measure the thickness of the Quaternary deposits in places where the bedrock was not reached with GPR. The soundings were made with a 12-channel Geometrics ES-1225 seismograph using a hammer to generate the shock waves. The locations of the GPR and refraction seismic lines are indicated in Fig. 2.

Two sets of pollen slides were made from the organic horizon of the paleosol (unit 6 in Fig. 4), following the preparation method of Bennet \& Willis (2001). One set was made with $5-\mathrm{cm}^{3}$ samples using $40 \%$ $\mathrm{HF}$ (cold), $10 \% \mathrm{KOH}$ and acetolysis treatment. Five Lycopodium tablettes were added to each sample. The other set was handled in a similar way, but using only 1- $\mathrm{cm}^{3}$ samples (1 Lycopodium tablette/sample) without acetolysis treatment. Both pollen and preserved cell tissue were analysed from the slides. In addition, two diatom slides were examined (preparation e.g. in Battarbee et al., 2001) from the varved silty layer (unit 3 in Figs. 4 and 5). Macroscopic plant remains in the paleosol, as well as, minerals of the sand grains in the paleosol and the Holocene soil parent materials were checked with a stereomicroscope.

Two sand samples from the paleosol section were dated with optically stimulated luminescence (OSL) method. The OSL method is used to estimate the point of time, when sediment grains have latest been exposed to daylight before burial under younger sediments (for details, see e.g. Balescu et al., 1997; Murray \& Olley, 2002). After removing 10-20 cm sediment from a section wall, a 40-cm-long and 7-cmwide plastic tube was hammered into the sediment. Several centimetres thick piece of folded paper and a plastic cap and tape was put on the hit end to prevent light from entering the tube during hammering. After the hammering, also the other end was carefully capped with a plastic cap and a tape. The sample tube was wrapped in an aluminium foil for storage.

The OSL samples in this study were dated with the SAR protocol (single-aliquot regenerative-dose protocol) from quartz grains. The datings were made in the Department of Physical Sciences, University of 
Helsinki, with the Risø TL-DA reader and blue LED lights. The beta dose rates were measured from sand samples with a Risø GM-25-5 beta multicounter. Sample treatment and measurement were analogous to that described by Salonen et al. (2008). The used method and equipment are more thoroughly described in Bøtter-Jensen \& Duller (1992), BøtterJensen et al. (1999) and Murray \& Wintle (2000).

One radiocarbon age determination was made from charred wood pieces (13.2 g of wood fragments) from the organic horizon of the paleosol. The sample (Su-3659) was analysed with the conventional gas proportional $\left(\mathrm{CO}_{2}\right.$ as the measurement gas) decay counting technique (e.g. Olsson, 1986; Björk \& Wohlfarth, 2001) in the Radiocarbon laboratory of the Geological Survey of Finland. A half-life of $5568 \pm 30$ years was used, normalized to $\delta^{13}=-25 \%$ in the PDB-scale. The obtained age is given in radiocarbon years without calibration.

In addition, bulk density, loss-on-ignition (LOI), magnetic susceptibility (Bartington instruments, model MS2, measured in situ) and colour (Munsell soil colour charts) determinations were made to compare the physical properties of the paleo- and the Holocene soils.

\section{Results}

According to the GPR and seismic measurements, the thickness of the Quaternary deposits is $20-24 \mathrm{~m}$ at the highest part of the Penttilänkangas ridge (GPR $A, B$ and $C$ and $S 1$ and $S 2$ in Fig. 2). The thickness decreases to $2-5 \mathrm{~m}$ in the southwestern part (Figs 3 and 5). In the Kodesjoki river valley, on the other hand, solid bedrock was not reached with the hammer seismic method (S3 in Fig. 2), indicating that its depth is more than $30 \mathrm{~m}$.

Nine sedimentary units are detected at Penttilänkangas. Six of the units are visible at the open section (dot 1 in Fig. 2), and the three lowermost units were interpreted from the GPR and seismic measurements. The identified units are as follows, starting from the top (unit 9):

- unit 9: weakly stratified sand and gravel
- unit 8: massive fine-rich diamicton

- unit 7: medium-grained stratified sand

- unit 6: medium- and coarse-grained stratified sand, paleosol profile

- unit 5: boulder lag

- unit 4: stratified sand and gravel with cobbles

- unit 3: varved silt and clay

- unit 2: cobble gravel

- unit 1: sand-rich diamicton

The units are described and interpreted in Table 1 and in Fig. 4. Cross-section across the Penttilänkangas ridge is presented in Fig. 5. The paleosol profile has been formed in unit 6 and the permafrost features in units 4-7. The paleosol was compared to the Holocene podzol soil in the same area (dot 2 in Fig. 2). The paleosol, comparison of the soils and description of the permafrost features are presented below.

Lithological analyses show that the clasts of unit 9 are derived mostly from unit 4; only a minor part of the clasts were derived from the overlying till of unit 8 (Fig. 6). This is expectable, as gravel is more susceptible to wave erosion than compact fine-grained till. It also demonstrates that the till layer is not continuous, and the gravel below the till has been exposed to direct wave erosion.

\section{I Paleosol profile}

A sand unit (unit 6) fills a shallow depression at the northeastern section of the gravel pit. The sand is medium to coarse-grained, massive and partly deformed with occasional pebbles. It reaches a maximum thickness of $70 \mathrm{~cm}$ in the middle of the section. The whole sand unit has been podzolised. The observed sandfilled depression is about $25 \mathrm{~m}$ wide, and the soil profile is visible along the whole depression (Figs. $7 \mathrm{a}$ and b).

The soil profile is mostly uniform, except in the central part of the section, where it has been folded and plastically deformed (Fig. 7c). The thickness of the visually distinguishable soil profile varies between 40 and $70 \mathrm{~cm}$. The organic-rich horizon with mineral matter (Ah), eluvial (albic, Ae), illuvial (enrichment, B) and intact parent material (C) horizons are clearly 
Table I. Description and interpretation of the observed units at the Penttilänkangas paleosol section (location indicated in Figs I and 2). Correlation to previously described deposits is indicated, and two new formal names, the Kodesjärvi Formation and Isojoki Sand, are proposed.

\begin{tabular}{|c|c|c|c|c|}
\hline $\begin{array}{l}\text { Description } \\
\text { and number of } \\
\text { the unit }\end{array}$ & Texture, structure, dating & $\begin{array}{l}\text { Observed } \\
\text { thickness and } \\
\text { contact to the } \\
\text { lower unit }\end{array}$ & $\begin{array}{l}\text { Interpretation and examples of } \\
\text { references, where similar de- } \\
\text { posits have been described }\end{array}$ & $\begin{array}{l}\text { Formal } \\
\text { name (with } \\
\text { references) }\end{array}$ \\
\hline $\begin{array}{l}\text { Unit 9: } \\
\text { Weakly stratified } \\
\text { or structureless } \\
\text { sand and gravel }\end{array}$ & $\begin{array}{l}\text { - slightly inclined or horizontal strati- } \\
\text { fication }\end{array}$ & $\begin{array}{l}-0.5-3 \mathrm{~m} \\
- \text { erosive }\end{array}$ & - shore deposit & $\begin{array}{l}\text { Lumikangas } \\
\text { Formation } \\
\text { (Pitkäranta, } \\
\text { 2005) }\end{array}$ \\
\hline $\begin{array}{l}\text { Unit 8: } \\
\text { Massive fines- } \\
\text { rich diamicton }\end{array}$ & $\begin{array}{l}\text { - compact and very dark grey (Munsell } \\
\text { colour N3/) } \\
\text { - well-developed fabric dipping to the } \\
\text { north }\end{array}$ & $\begin{array}{l}-0-3 \mathrm{~m} \\
- \text { erosive }\end{array}$ & - lodgement till & $\begin{array}{l}\text { Kauhajoki } \\
\text { Till (Bou- } \\
\text { chard et al., } \\
1990)\end{array}$ \\
\hline $\begin{array}{l}\text { Unit } 7: \\
\text { Medium-grained } \\
\text { stratified sand }\end{array}$ & $\begin{array}{l}\text { - horizontal stratification, charcoal } \\
\text { streaks } \\
\text { - both brittle and plastical deformation } \\
\text { - OSL age } 65 \pm 9.9 \mathrm{ka} \text { (see discussion) }\end{array}$ & $\begin{array}{l}-0-0.7 \mathrm{~m} \\
- \text { erosive }\end{array}$ & $\begin{array}{l}\text { - eolian sand } \\
\text { - post-depositional cryoturba- } \\
\text { tion and glaciotectonism }\end{array}$ & Isojoki Sand* \\
\hline $\begin{array}{l}\text { Unit 6: } \\
\text { Medium- to } \\
\text { coarse-grained } \\
\text { sand, podzolised }\end{array}$ & $\begin{array}{l}\text { - partly deformed (tectonized), occa- } \\
\text { sional cobbles and pebbles } \\
\text { - OSL age from the eluvial horizon } 72 \\
\pm 4.8 \mathrm{ka} \\
\text { - radiocarbon age from the organic ho- } \\
\text { rizon } 48.2(+4.5 /-3.1) \mathrm{ka} \\
\text { - see further description in text and in } \\
\text { Figs } 6-8\end{array}$ & $\begin{array}{l}-0-0.7 \mathrm{~m} \\
- \text { abrupt }\end{array}$ & $\begin{array}{l}\text { - beach sand } \\
\text { - emergence and soil formation } \\
\text { in humid temperate subaerial } \\
\text { conditions } \\
\text { - post-depositional cryoturba- } \\
\text { tion and glaciotectonism }\end{array}$ & $\begin{array}{l}\text { Ostrobothnia } \\
\text { Geosol (Ku- } \\
\text { jansuu et al., } \\
1991)\end{array}$ \\
\hline $\begin{array}{l}\text { Unit 5: } \\
\text { Boulder lag }\end{array}$ & $\begin{array}{l}\text { - very well rounded (some almost } \\
\text { spherical) cobbles and boulders are } \\
\text { around } 20-60 \mathrm{~cm} \text { in diameter } \\
\text { - no imbrication, disc- and rod-shaped } \\
\text { clasts lie preferably horizontally }\end{array}$ & $\begin{array}{l}-\sim 0.6 \mathrm{~m} \\
- \text { erosive }\end{array}$ & $\begin{array}{l}\text { - shore deposit (lag horizon) } \\
\text { - Fyfe (1990) }\end{array}$ & \multirow[t]{2}{*}{$\begin{array}{l}\text { Kodesjärvi } \\
\text { Formation* }\end{array}$} \\
\hline $\begin{array}{l}\text { Unit 4: } \\
\text { Stratified sand } \\
\text { and gravel with } \\
\text { cobbles }\end{array}$ & $\begin{array}{l}\text { - coarsening upwards, low angle } \\
\left(5-10^{\circ}\right) \text { large-scale cross-bedding } \\
\text { - sand interlayers with planar and } \\
\text { through cross-bedding } \\
\text { - upper } 1-2 \text { m crudely bedded cob- } \\
\text { ble gravel } \\
\text { - dip directions to the NNE-ENE } \\
\text { - deformations, ice-wedge casts (Fig. 5) }\end{array}$ & $\begin{array}{l}-4-6 \mathrm{~m} \\
- \text { abrupt }\end{array}$ & $\begin{array}{l}\text { - shore deposit: washover } \\
\text { (Schwarz, 1982; Massari \& Pa- } \\
\text { rea, 1988) or prograding spit- } \\
\text { platform deposit (Nielsen, 1988; } \\
\text { Novak \& Pedersen, 2000; Mäk- } \\
\text { inen \& Räsänen, 2003) } \\
\text { - post-depositional glaciotecton- } \\
\text { ism and ice-wedge cracking } \\
\text { - cf. GPR images in Smith \& } \\
\text { Jol (1992); Møller \& Dennis } \\
(2003) \text {; Smith et al. (2003) } \\
\end{array}$ & \\
\hline $\begin{array}{l}\text { Unit 3: } \\
\text { Varved silt/clay }\end{array}$ & $\begin{array}{l}\text { - single varve thickness } 2-20 \mathrm{~mm} \\
\text { - no microfossils }\end{array}$ & $\begin{array}{l}-\sim 0.5 \mathrm{~m} \\
- \text { conformable }\end{array}$ & $\begin{array}{l}\text { - glaciomarine/ -lacustrine } \\
\text { - Eyles \& Eyles (1992); Gilbert } \\
\text { et al. (1997); Cofaigh \& Dowd- } \\
\text { eswell (2001) }\end{array}$ & \multirow{2}{*}{$\begin{array}{l}\text { Harrinkangas } \\
\text { Formation } \\
\text { (?) (Gibbard } \\
\text { et al., 1989; } \\
\text { Bouchard et } \\
\text { al., 1990) }\end{array}$} \\
\hline $\begin{array}{l}\text { Unit 2: } \\
\text { Cobble gravel }\end{array}$ & $\begin{array}{l}\text { - large-scale cross-bedding, locally de- } \\
\text { formed (folds) }\end{array}$ & $\begin{array}{l}-12-16 \mathrm{~m} \\
- \text { abrupt }\end{array}$ & $\begin{array}{l}\text { - subaquatic ice-contact fan } \\
\text { - ice-push deformation } \\
\text { - Benn \& Evans (1996, 1998); } \\
\text { Lunkka \& Alhonen (1996); Løn- } \\
\text { ne (1995) }\end{array}$ & \\
\hline $\begin{array}{l}\text { Unit 1: } \\
\text { Sand-rich } \\
\text { diamicton with } \\
\text { boulders }\end{array}$ & $\begin{array}{l}\text { - structures can not be detected in the } \\
\text { GPR measurements }\end{array}$ & $\begin{array}{l}-1-4 \mathrm{~m} \\
- \text { lies on the } \\
\text { bedrock }\end{array}$ & - till & $\begin{array}{l}\text { Kariluo- } \\
\text { ma Till (?) } \\
\text { (Pitkäranta, } \\
\text { 2005, 2009) }\end{array}$ \\
\hline
\end{tabular}

\footnotetext{
* Name proposed in this study.
} 
A)

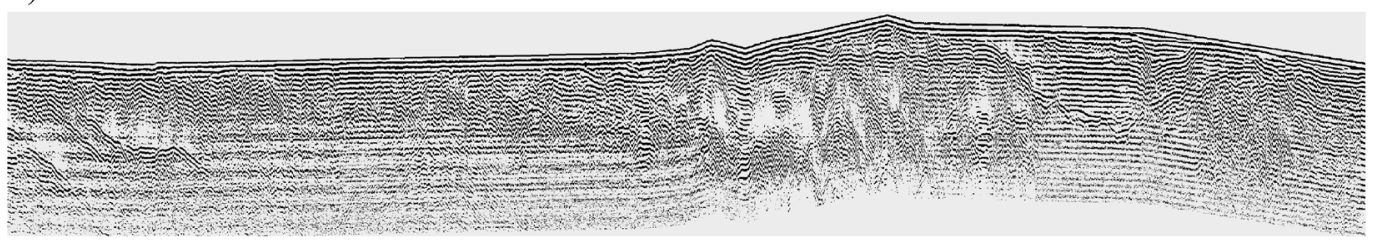

SW

$\mathrm{NE}$

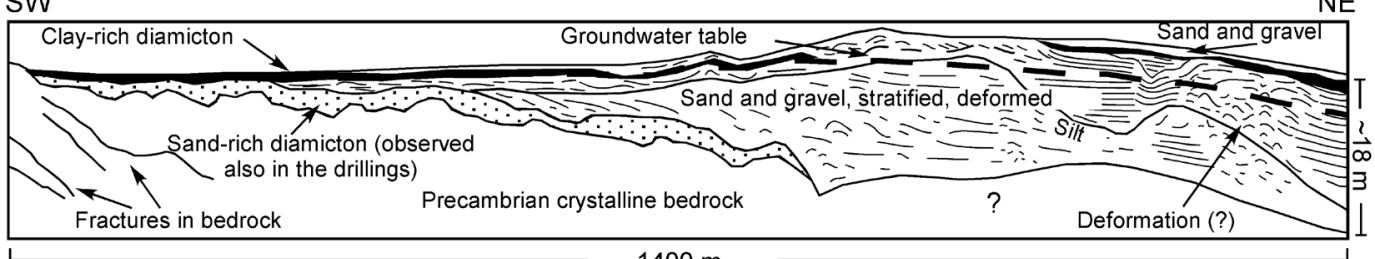

$\varepsilon_{\mathrm{r}}=5$ above and 16 below ground water table

$1400 \mathrm{~m}$

Time window 510 ns (RAMAC/GPR)

B)

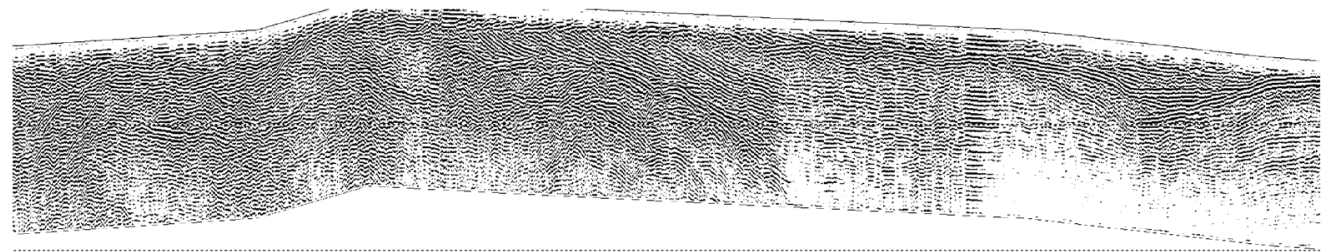

SW

$\mathrm{NE}$

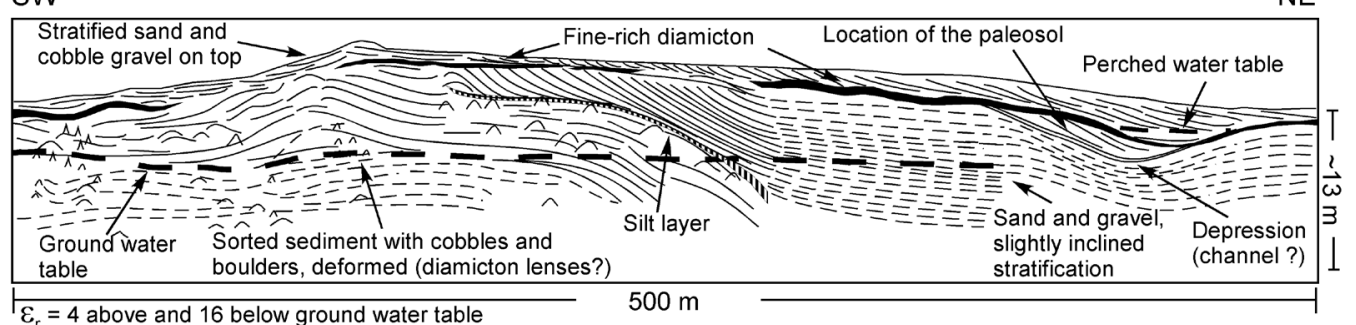

$\varepsilon_{\mathrm{r}}=4$ above and 16 below ground water table

Time window $250 \mathrm{~ns}$ (SIR-10)

C)

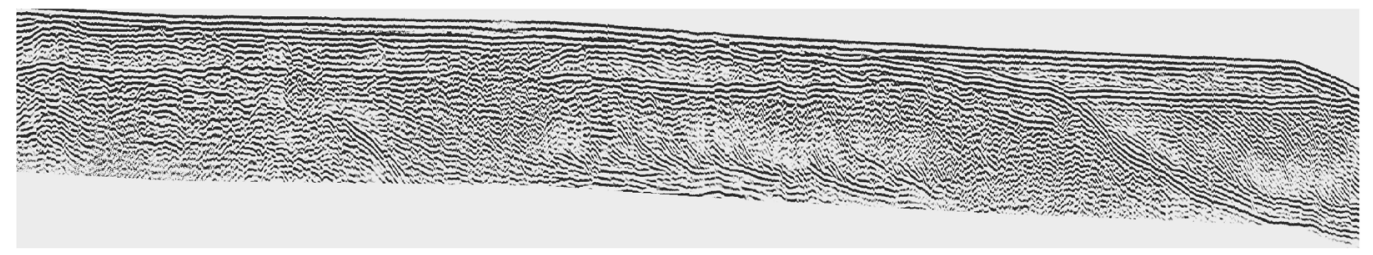

SW

NE

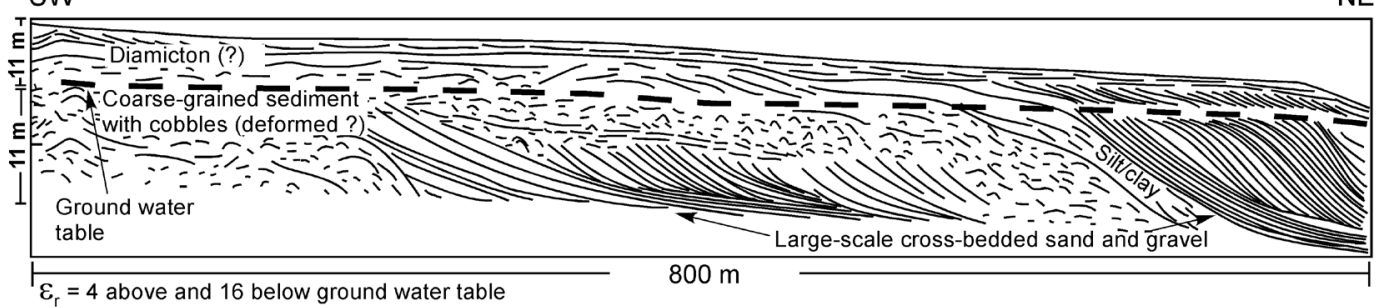

Time window 420 ns (RAMAC/GPR)

Fig. 3. GPR images (locations in Fig. 2) across the Penttilänkangas ridge show the internal architecture of the Penttilänkangas deposit: A) profile starting from the bedrock area in the SW, and continuing across the Penttilänkangas ridge (RAMAC/GPR); B) the latter $500 \mathrm{~m}$ of the a-profile with SIR-10 and different measurement settings; C) crosssection of the western part of Penttilänkangas. Major sedimentary units can be detected in the images. 


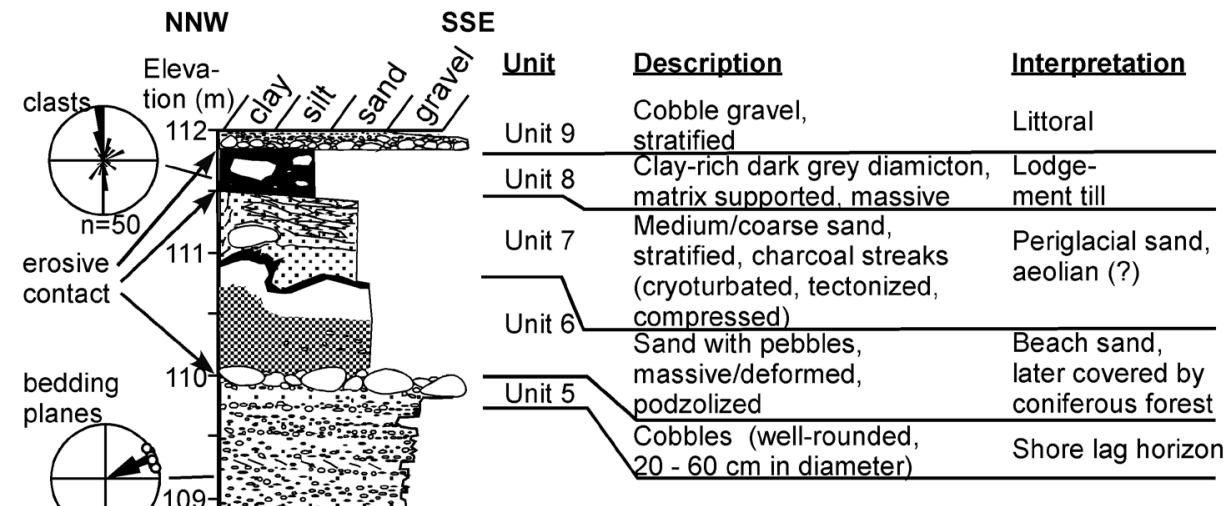
coarsening upwards,

Regressive prograding ice-wedge cast, compressed shore deposits

\begin{tabular}{|c|c|c|}
\hline Unit 3 & Varved clay and silt & $\begin{array}{l}\text { Proglacial } \\
\text { lake/sea }\end{array}$ \\
\hline
\end{tabular}

\section{Unit 2 Stratified gravel with cobbles Glaciofluvial, and boulders, deformed ice contact}

Fig. 4. Illustration, description and interpretation of the lithofacies in the Penttilänkangas section. 


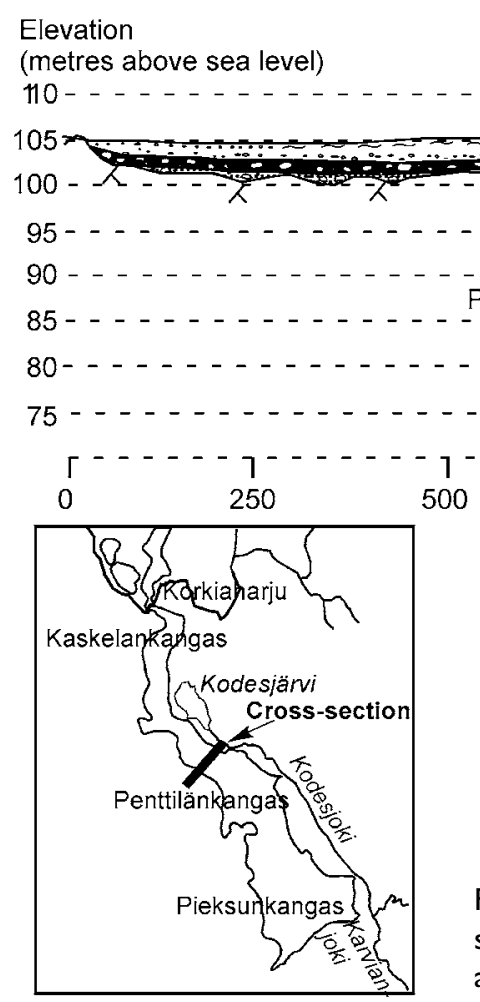

Fig. 5. Cross-section across the Penttilänkangas ridge shows the spatial relationships of the identified units (see text and Fig. 4). Units 5-7 are not distinquish-

Fig. 6. Clast lithologies of units 4,8 and 9 indicate that material in the shore deposits were mostly derived from the unit 4 , not the till of unit 8 . This implies that the till layer has been thin or missing at places.
Precambrian bedrock

Unit 7 (sand above the paleosol)

Unit 6. (enrichment horizon in the paleosol)

Unit 5. (boulder lag)

Kodesjoki -river yalley

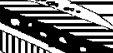<smiles>[13CH3]</smiles>
? -Fractured bedrock 1250 1500 $\left\{\begin{array}{l}-\Gamma^{-} \\ 1750 m\end{array}\right.$ able at the presented scale. 750 500
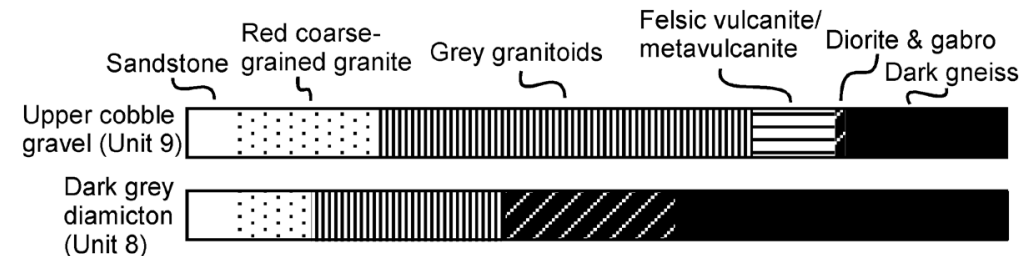
(Unit 8)

Lower stratified gravel (Unit 4)

I 1

distinguishable. The organic horizon has been partly eroded. Organic material occurs also in the upper stratified medium-grained sand (unit 7 in Table 1). All the detected organic material seems to be charred. The charcoal is mostly fine-grained powder, but also 1-10 $\mathrm{mm}$ pieces can be found.

The organic horizon and the organic streaks in the upper sand have low pollen content. After analysing eleven slides (1277 added Lycopodium spores count- ed), only the following pollen grains were found (amount of grains in parenthesis): Betula (3), Pinus (10), Alnus (11), ?Corylus (5), Carpinus (1), Salix (3), Calluna (2), Ericacea (5), Poaceae (17), Rosaceae (2), Typha (1). In addition, up to 60 grains were detected that resembled pollen but were so heavily ruptured that they could not be identified.

Contrary to the weak pollen content, pieces of opaque charcoal and remains of coniferous cell tis- 
sue are found in abundance on the slides (Fig. 8). Abundant coniferous charcoal pieces are also easily detectable with naked eyes. Some physical characteristics (colour, grain size, magnetic susceptibility, bulk density and LOI) of the paleosol are compared to the Holocene podzol soil profile in Fig. 9a-c. This comparison is used to estimate the climatic conditions and time required for the podzolisation of the paleosol, as those of the Holocene soil are fairly well known (see below).

The OSL age of the eluvial horizon is $72 \pm 4.8 \mathrm{ka}$ and that of the sand above (unit 7) is $65 \pm 9.9 \mathrm{ka}$ (Ta- ble 2). The conventional (uncalibrated) radiocarbon age for the charred organic material (sample Su-3659) above the eluvial horizon is $48.2(+4.5 /-3.1) \mathrm{ka}$.

\subsection{Comparison of the physical properties between the paleosol and the Holocene podzol soil}

The studied Holocene podzol soil profile $(100 \mathrm{~m}$ above sea level) is situated $1.7 \mathrm{~km}$ to SW from the Penttilänkangas section. The location of the soil profile is indicated in Fig. 2 (dot 2) and an image of it in Fig. $7 \mathrm{~d}$. The study site emerged from the sea about
A)

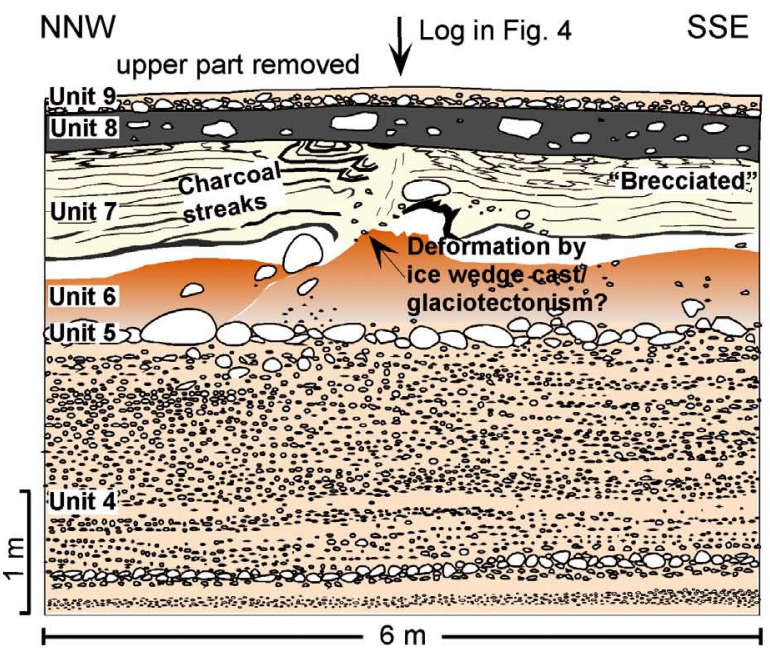

C)

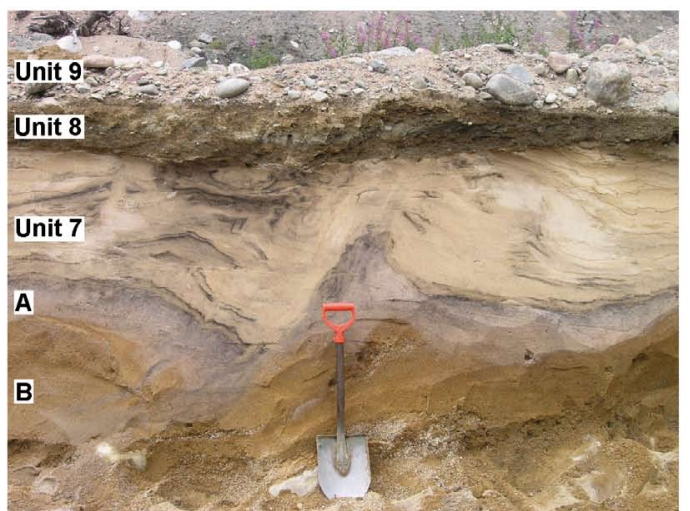

B)

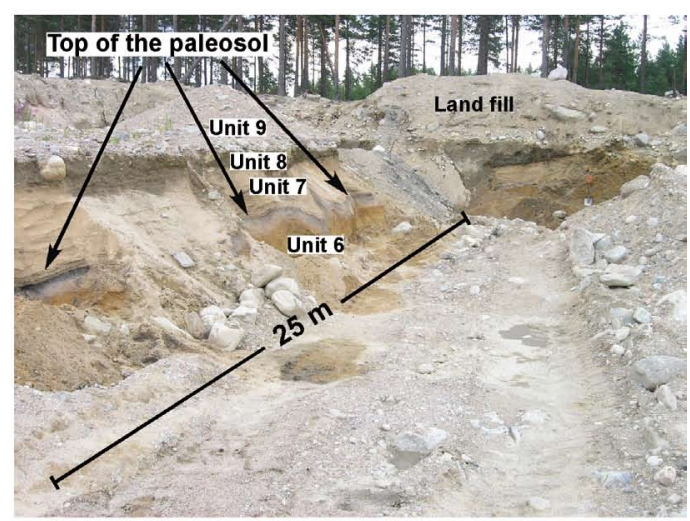

D)

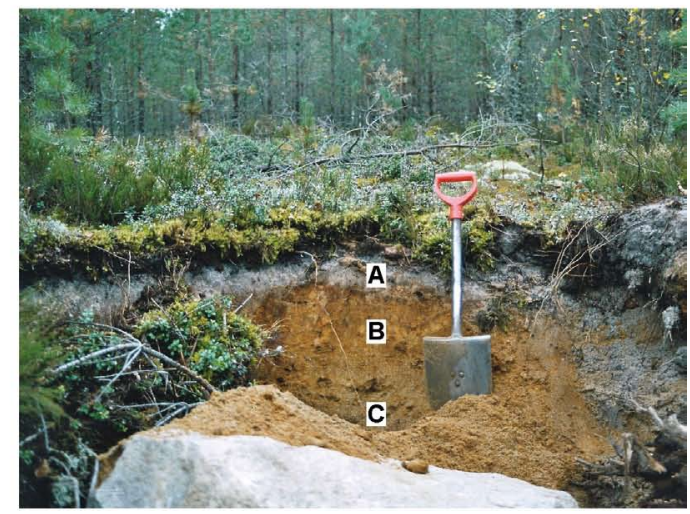

Fig. 7. A) The paleosol section. The big clasts in the units 6 and 7 have risen to their positions due to glaciotectonism or alternatively by frost heave. B) Photo of the lateral extent of the paleosol. The section is facing to southeast. C) Disturbed soil profile in the center of the section. D) The Holocene podzol soil profile, which is compared to the paleosol (see Fig. 9). 

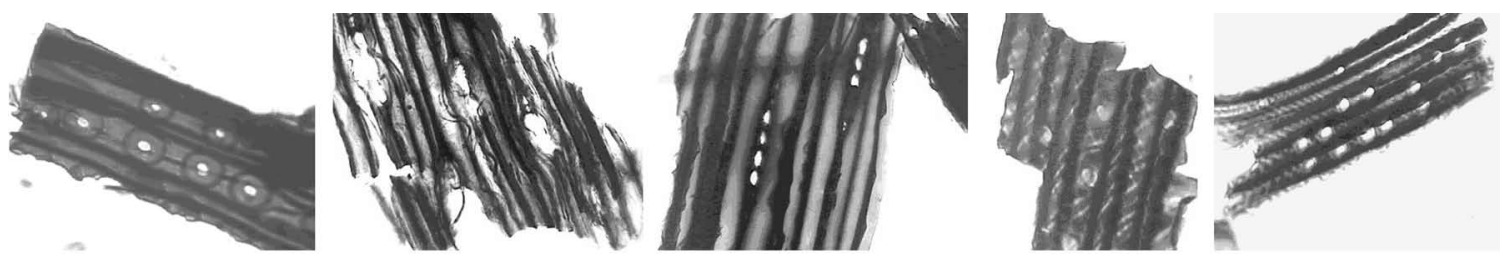

$0.5 \mathrm{~mm}$

Fig. 8. Pieces of coniferous tree cell tissue, probably spruce and/or pine, from the charred organic horizon of the fossil podzol soil.

Table 2. OSL results from the two sand samples in the paleosol section. The water content of sands during the time of burial has been estimated to be $20 \%$

\begin{tabular}{|c|c|c|c|c|c|}
\hline $\begin{array}{l}\text { Co-ordinates } \\
\text { (WGS84) }\end{array}$ & Sample code & Material sampled & Genesis of the sample material & Paleodose & Age (ka) \\
\hline $\begin{array}{l}\mathrm{E} 22.0731^{\circ} \\
\mathrm{N} 62.0280^{\circ} \\
109 \mathrm{~m} \text { a.s.l. }\end{array}$ & $\begin{array}{l}\text { Kode } 2 \\
\text { (Hel-TL04008) }\end{array}$ & Medium sand & Eolian & $\begin{array}{l}142 \mathrm{~Gy} \pm 14.4 \% \\
(2.18 \mathrm{mGy} / \mathrm{a})^{*}\end{array}$ & $65 \pm 9.9$ \\
\hline $\begin{array}{l}\mathrm{E} 22.0729^{\circ} \\
\mathrm{N} 62.0281^{\circ} \\
109 \text { m a.s.l. }\end{array}$ & $\begin{array}{l}\text { Kode } 1 \\
\text { (Hel-TL04007) }\end{array}$ & Medium sand & $\begin{array}{l}\text { Shore deposit, eluvial horizon in } \\
\text { fossil podzol soil profile }\end{array}$ & $\begin{array}{l}130 \mathrm{~Gy} \pm 4.4 \% \\
(1.82 \mathrm{mGy} / \mathrm{a})^{*}\end{array}$ & $72 \pm 4.8$ \\
\hline
\end{tabular}

8100-8400 BP according to the shore-level displacement curves of Salomaa (1982) and Glückert et al. (1993). The soil forming process started to develop soon after it emerged from the sea, as the climate was already humid and temperate at that time. Thus, the Holocene soil should be both physically and chemically mature. It also developed in a similar parent material and in the same area as the paleosol. Comparing the properties of these two podzols is thus appropiate, although too strict conclusions can not be made.

The physical properties in Fig. 9 show that the podzolisation is stronger and the soil profile is on average $40 \%$ thicker in the paleosol than in the Holocene soil. This is demonstrated by the slightly more distinct enrichment of clay and fine silt particles in the upper part of the B horizon, thicker zonation of the bulk density and LOI values, and more powerful magnetic susceptibility variations in the paleosol than in the Holocene soil. The dry bulk density values in the paleosol are on average 5-10\% higher, be- cause it was under the pressure of continental ice. The lower LOI values in the paleosol, in turn, may originate from post-depositional leaching (cf. Karlström \& Osborn, 1992). The hues are slightly redder in the paleosol than in the Holocene soil. The magnetic susceptibility is weak in both soils. The differences between the soils are discussed below.

\subsection{Permafrost features}

Cryoturbation and narrow ice-wedge casts are found on the walls of the Penttilänkangas quarry (Fig. 7a and c; Fig. 10). The ice-wedge casts have been formed in the stony gravel of unit 4 . They are $10-20 \mathrm{~cm}$ wide and about $4 \mathrm{~m}$ deep. Cryoturbation is formed in the sand of units 6 and 7. These types of permafrost phenomena are common in this region (Pitkäranta, 2009). For example at Kiviharju, in the same eskerlike ridge as Penttilänkangas (see location in Fig. 1), cryoturbation, as well as, up to 1.2 metres wide icewedge cast are found (Fig. 11). 
A)

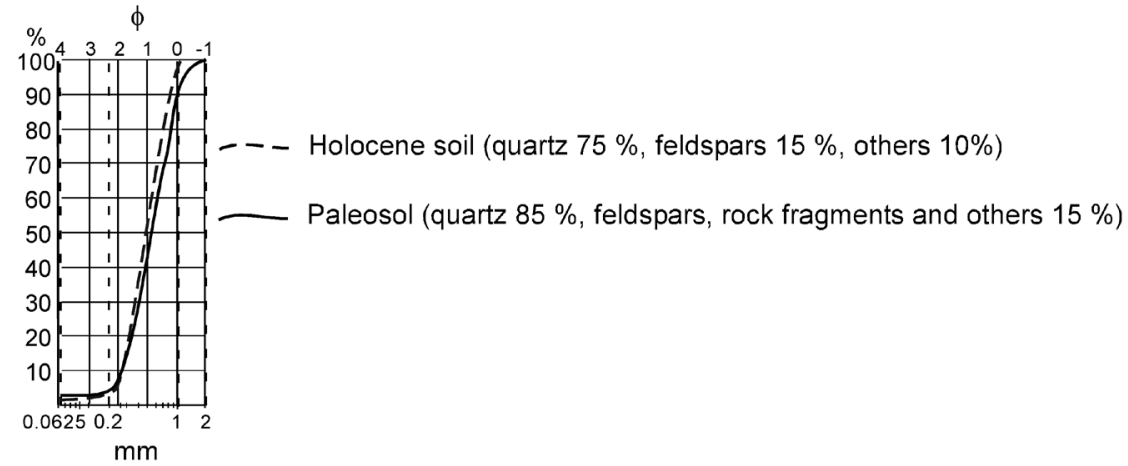

B)

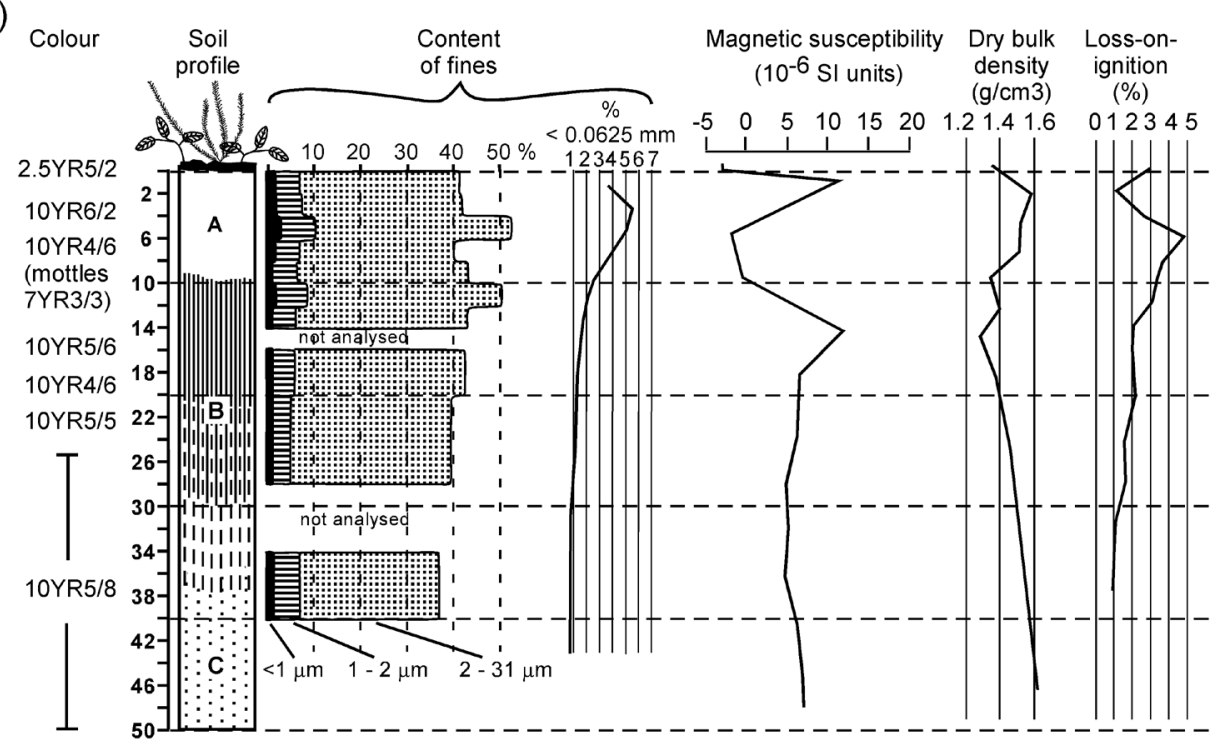

C)

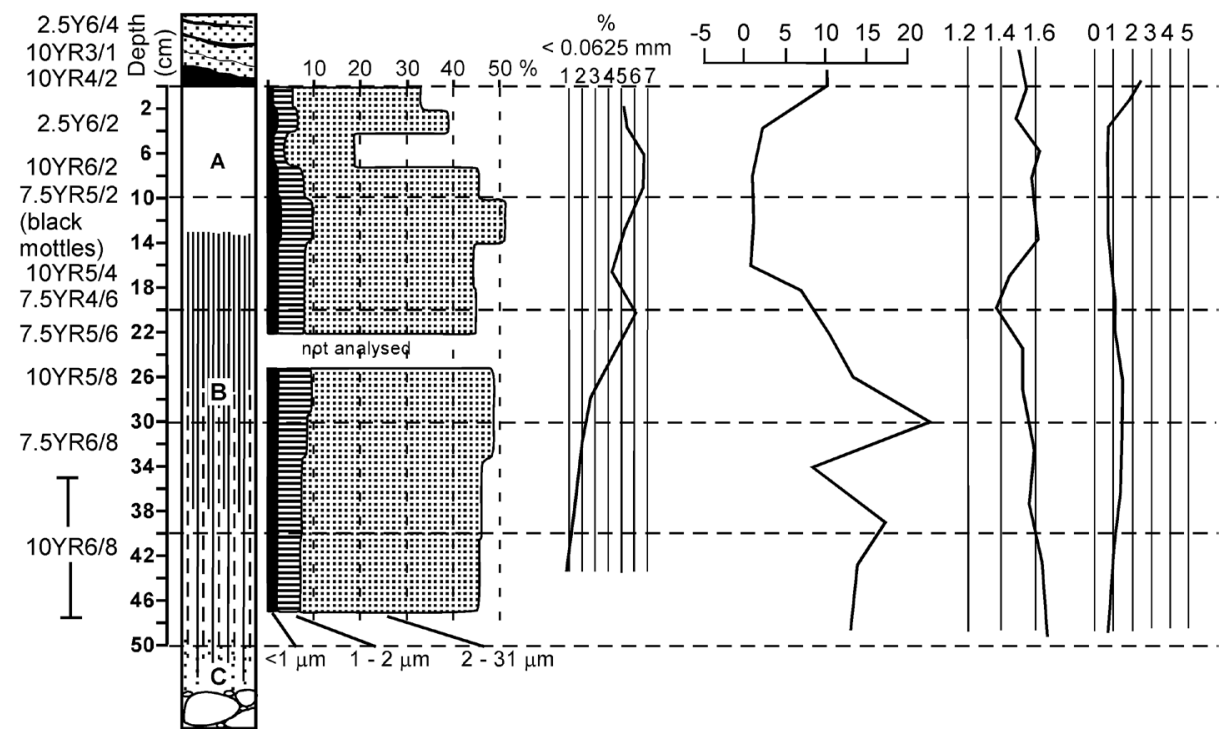

Fig. 9. Comparison of physical properties of the Holocene and the buried podzol soil profiles: A) grain size curves and mineralogy of the parent materials of the soils; B) Holocene soil; C) Paleosol. 


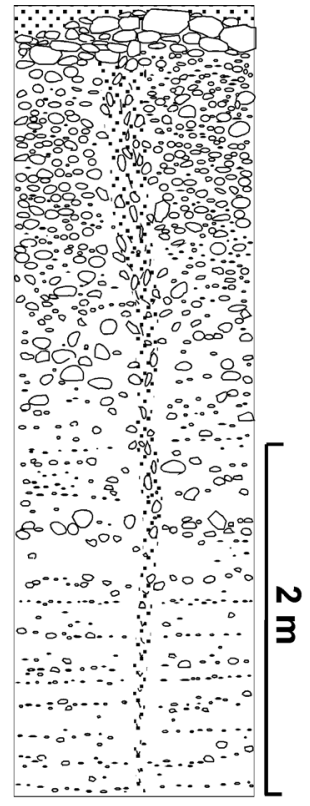

\section{Discussion}

Lithostratigraphy of the upper part of the Penttilänkangas section is analogous to the paleosol sites at Kärjenkoski, Risåsen, Norinkylä and Harrinkangas, described by Niemelä \& Tynni (1979), Kujansuu et al. (1991), Kujansuu (1992) and Hütt et al. (1993) (see Fig. 1). Kujansuu et al. (1991), Kujansuu (1992) and Hütt et al. (1993) have interpreted these paleosols as originating from the Eemian Stage (marine isotope stage [MIS] 5e, Martinson et al., 1987), or possibly from the temperate phases of the Early Weichselian Substage (MIS 5a and 5c). They named the paleosols formally as the "Ostrobothnia Geosol" according to the usage of the North American Commission on Stratigraphic Nomenclature (1982). Their interpretation is based on the stratigraphy, chemical maturity of the soils and on several TL and OSL age determinations made by them and by Gibbard et al. (1989) and Niemelä \& Jungner (1991). The paleosol at Penttilänkangas possibly correlates to the Ostrobothnia Geosol.

The radiocarbon age from Penttilänkangas is close to the theoretical limit of the method, which has commonly been put at 40-45 ka (e.g. Björck \& Wohlfarth, 2001). Hence, the measured age of $48200(+4500$

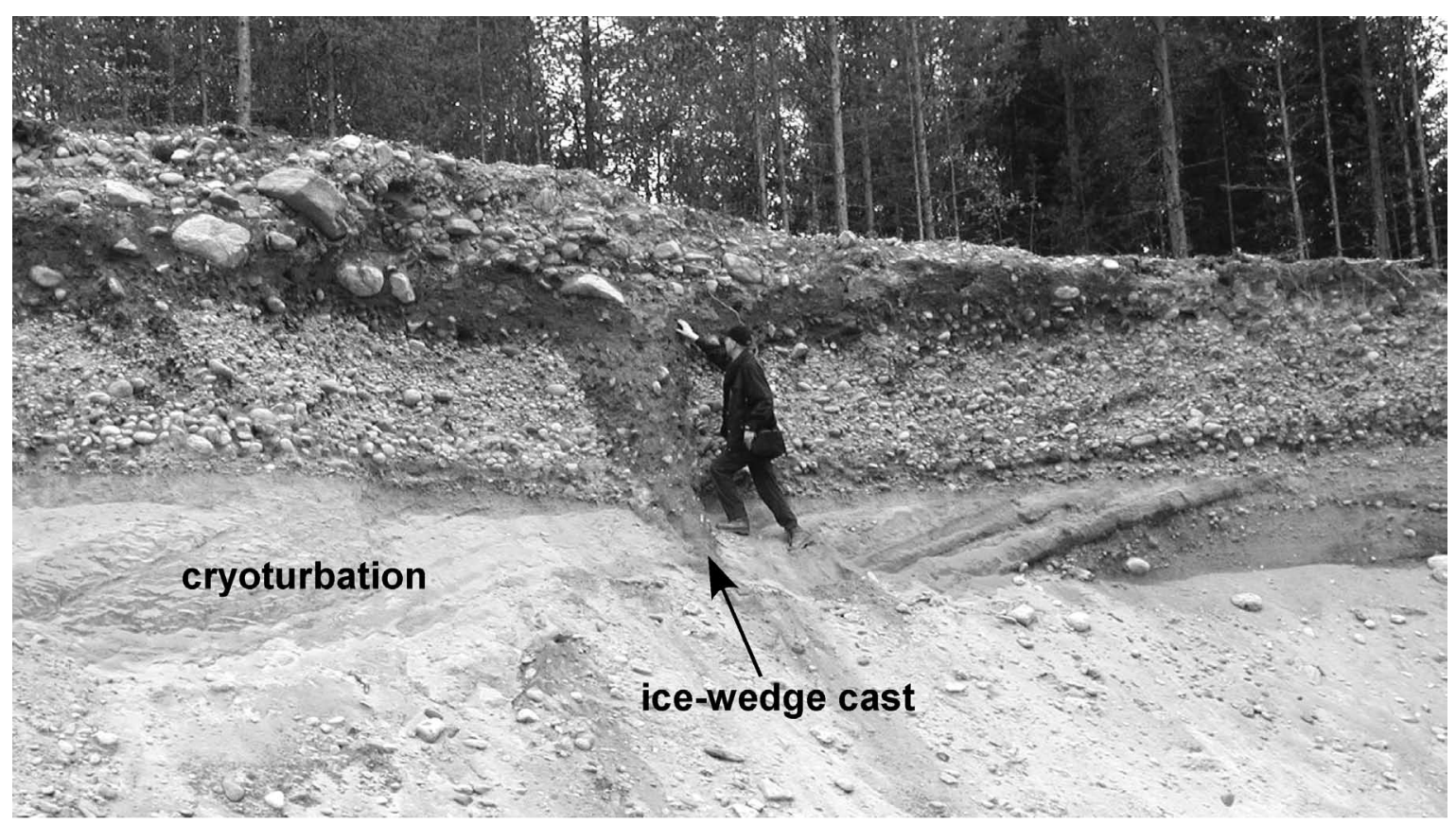

Fig. II. Cryoturbation and I.2-m-wide ice-wedge cast at Kiviharju in the same esker-like ridge as Penttilänkangas. The cracking of the wedge has taken 1000 years or more (see text). 
I -3100) years for the organic horizon should be regarded as the minimum age for the material. The radiocarbon date, however, implies at least a Middle Weichselian age for the paleosol.

The OSL ages presented in this study are considerably younger than those reported by Hütt et al. (1993) from both below and above the paleosol profiles at Kärjenkoski, Risåsen and Norinkylä. If correct, the OSL date $(72 \pm 4.8 \mathrm{ka})$ from the eluvial horizon of the paleosol at Penttilänkangas implies that the sand deposited not until the beginning of the Middle Weichselian Substage and the soil had started to develop after that. This is not in full agreement with previous interpretations. Possible variations of dose rate during burial time of sediments (because of changes in water content or nuclide leaching), as well as, low sensitivity of quarz and incomplete bleaching, must be considered as uncertainties in OSL dating (HoumarkNielsen, 2008; Fuchs \& Owen, 2008). For example, Houmark-Nielsen (2008) reported up to $60 \%$ underestimation in age, when sediment with a known age (Eemian) was tested with the OSL method. It is also possible that dated grains have got light after their original deposition, e.g. by deformation (c.f. Kjær et al., 2006).

According to the oxygen isotope curves, global sea levels and temperatures started to drop dramatically at $74 \mathrm{ka}$ ago (Chappel \& Shackleton, 1986; Martinson et al., 1987), and the younger of the Weichselian interstadials, the Odderade (MIS 5a), was just turning to the cooler episode of the Middle Weichselian (MIS 4). Hence, the climatic conditions were unfavourable for podzol soil formation at that time, which contradicts with the OSL age from the eluvial horizon.

Also the water level of the Bothnian Sea is assumed to have been lower in the Early Weichselian than at present (Nenonen, 1995). This contradicts to the interpretation that unit 6 , as well as units 5 and 4 , were deposited by wave action in a littoral zone of a large water body (sea), as the study area is more than $100 \mathrm{~m}$ above the present sea level. At approximately the same time, a shallow lake was occupying a depression at the present sea level on Björkö Island near Vaasa, 150 km to the NNW from Penttilänkangas (Auri \& Räsänen, 2006; Auri et al., 2006). Thus, the measured OSL age from the eluvial horizon should be regarded with caution. On the other hand, the age $(65 \pm 9.9 \mathrm{ka})$ for the upper eolian sand, which probably has been deposited in periglacial environment, is possibly correct. Fairly late ice expansion in Middle Weichselian is supported also by the observations of Lunkka et al. (2008) in eastern Finland, where ice advanced not until $52 \mathrm{ka}$ ago (see also Kleman et al., 1997), although Holmlund \& Fastook (1995) suggested that all of Finland was covered by ice at $65 \mathrm{ka}$ ago.

The paleosol horizons at Penttilänkangas are fairly thick and well differentiated (strongly or very strongly developed in the rank of Follmer, 1998), which demonstrates that the soil forming process lasted for a long time and/or occurred in a favourable climate. Coniferous forest was growing at the site at the time of the podzolisation, and no active eolian sedimentation could have been taking place at the same time. After the forest disappeared (or burned, deducing from the abundance of charcoal), eolian erosion and sand deposition was initiated. Despite several uncertainties (see Bockheim, 1979; Boardman, 1985; Catt, 1991) in the known processes, minimum time estimates for the development of podzol soils and permafrost structures can be given. These are discussed below.

Soil formation is dependent on the parent material, topography, climate, organisms and time (Jenny, 1941). If four variables remain more or less constant, the fifth can be resolved to some accuracy (Bockheim, 1980). For example, time as a variable in podzol-soil development has been studied in several papers in Finland (e.g. Jauhiainen, 1973; Starr 1991; Petäjä-Ronkainen \& Peuraniemi, 1992; Mokma et al., 2004), as well as, abroad (e.g. Bockheim, 1980; Birkeland, 1984; Karlström \& Osborn, 1992; see also the reviews in Lundström et al., 2000 and Mokma et al., 2004). The results vary considerably, but it can be concluded that physically and chemically distinguishable podzol soil forms over periods between 500 and 8000 years in sand-rich parent material. In addition to natural variables, the large variation in these figures 
depends partly on the soil classification system used, as each system uses different limits of physical and chemical properties (e.g. Mokma et al., 2004).

The strongly developed fossil podzol soil at Penttilänkangas with thick and well-differentiated horizons indicates climatic conditions in which the soil has abundant infiltrated waters during fall and spring times (Schaetzl \& Isard, 1991, 1996). This implies a humid climate with mild winters and/or thick snow cover before the soil freezes in autumn. Deep infiltration outside the growing season enhances the translocation of organometallic complexes into the B horizon, and hence strengthens podzolisation (Schaetzl $\&$ Isard, 1991, 1996). This suggests that the podzolisation took place approximately in the same type as or a moister climate than the present. In any case, it precludes the possibility of a periglacial environment during the time of the podzolisation, even though podzolisation can take place also in fairly cold climate (Tedrow, 1977; Birkeland, 1978; Bockheim, 1979).

Aging, high precipitation and high paleotemperatures increase the redness of a soil (Kemp, 1985). Although an uncertain criterion (see Schwertmann et al., 1982; Boardman, 1985; Catt, 1990), the slightly redder hues in the paleosol may originate from a warmer and wetter climate than the present.

The weak magnetic susceptibility of the paleo- and Holocene soils demonstrates that the content of both pedogenic and original (mineralogy in the unweathered parent material) magnetite and maghemite is low (see Mullins, 1977; Grimley et al., 2004). Low pH soil conditions $(<5.5)$, common under coniferous forest, limit the amount of pedogenic magnetite formation (Maher, 1998) and increase the rate of magnetite dissolution (Williams, 1992). Magnetic susceptibility also tends to have the higher values the more pedogenetically formed clay is present in the material, and the warmer and moister the climate is (Thompson \& Morton, 1979; Williams \& Cooper, 1990; Dearing et al., 1996). The slightly higher magnetic susceptibility, as well as, clearer and thicker zonation of magnetic minerals in the paleosol, possibly indicates a higher paleotemperature and higher $\mathrm{pH}$ than exists in the Holocene. The comparison between the pale- osol and the Holocene soil profile at Penttilänkangas demonstrates that the paleosol is at least as mature as the Holocene soil.

Studies in modern permafrost areas have shown that the width of an ice-wedge is, at least to some extent, proportional to the amount of time involved in its formation (e.g. Leffingwell, 1915; Maack, 1967; Black, 1976; MacKay, 1974, 1975, 1986). The reported cracking rates vary considerably, and are usually in the order of $1-35 \mathrm{~mm} /$ year. The width of crack is a poor indication of its age, since the wedges do not crack every year, the cracking rate slows down as the ice-wedge widens and the sediment adjacent to the wedge may fall into the wedge as slumps (Péwé, 1966; Black, 1976; MacKay, 1986; Harry \& Gozdzik, 1988). Thus, the ice-wedge casts at Penttilänkangas, which are several centimetres wide, possibly developed in roughly a few tens or hundreds of years. On the other hand, the $1.2 \mathrm{~m}$ wide wedge at Kiviharju, which belongs to the same esker-like ridge as Penttilänkangas (see the location in Fig. 1), formed over an interval of 1000 years or more (cf. Maack, 1967). Furthermore, the permafrost itself also takes a considerable amount of time to grow. For example, Delisle (1998) has calculated that the growth of 90$140 \mathrm{~m}$ deep permafrost in northern Germany and the Netherlands during the peak period of last glacial stage took roughly 10000 years and its decay about 2000 years.

The cryoturbation shown in Fig. 7a and c occurs only in the sand, not in the gravel below. This is partly because it occurs in the active layer, where deformable freezing and thawing repeatedly take place, and partly because cryoturbation structures develop more easily in sand than in stony gravel (Van Vliet-Lanoë, 1988, cf. examples of cryoturbated soils in Tedrow, 1977 and Tarnocai \& Valentine, 1989; Olsen, 1998). It should be stressed that cryoturbation as such does not definitely indicate permafrost, as it can form in rather humid and cold climates without permafrost (Van Vliet-Lanoë, 1988). Also, tree-fall may cause structures that resemble cryoturbation (Catt, 1990). Furthermore, vertical clastic dykes can sometimes be confused to ice-wedge casts (c.f. van der Meer et al, 
2009). However, the occurrence of ice-wedge casts at Penttilänkangas, as well as, elsewhere along the same ridge indicates that permafrost conditions really existed. Ice wedges only form in periglacial climate (Péwe, 1966; Black, 1976; Harry \& Gozdzik, 1988, Huijzer \& Vandenberghe, 1998).

The reasons that the paleosol could have preserved through the latest glaciation may be summarized as: 1) it developed in a shallow, sheltered depression filled with sand; 2) the sand was deeply frozen when the glacier overrode it; 3) the area was situated in the passive interstream lobe with cold-based ice and with weak glacial erosion during the latest glaciation (c.f. Punkari, 1997; Kleman et al., 1997; 2008); 4) low permeability of the overlying clay-rich till has prevented percolating waters from altering the soil horizons (see Catt, 1990, Olson \& Nettleton, 1998); 5) the position of paleosol beneath the active freezethaw layer in the Holocene has prevented further soil disturbance. At slightly higher positions, where the covering eolian sand is thin or lacking, the glacier has deformed the soil profile or totally removed it.

The uppermost dark grey massive till correlates to the Kauhajoki Till Formation, described by Gibbard et al. (1989) and Bouchard et al. (1990). This clearly distinguishable till has a large lateral continuity and is always the uppermost till in the area. It was laid down by the latest ice-sheet, which advanced into the area during the Late Weichselian Substage, at the latest. The dark colour of this till has been inferred as originating from the high clay content and from ferrous sulphides (Rainio \& Lahermo, 1976, 1984). Similar type of till has also been found in Sweden at the same latitudes as the area discussed here (Lundqvist, 1973; Björnbom, 1979; Robertsson et al., 2005), although correlation between these tills is difficult. The lithology analyses at Penttilänkangas (Fig. 6) indicate that this till has a considerable amount of dark-coloured rock fragments (both as cobbles and small pebbles in the matrix). This also contributes to the dark colour of the till. According to the bedrock map of southern Ostrobothnia (Korsman et al., 1997; Lehtonen et al., 2004), large areas with dark rocks occur particularly to the northwest from Penttilänkangas, i.e. roughly corresponding to the direction of the latest ice movement.

The well-aerated sand-rich soil and forest fires are probable reasons for the negligible preservation of pollen grains in the organic horizon of the paleosol. If the pollen wall is highly oxidized, it will easily be decayed by microbial attack. Fire may effectively destroy all the pollen, especially in the topmost few centimetres (Havinga, 1967). Havinga (1967) also noted that pollen preservation is especially poor in podzol soils. The low pollen content in the studied paleosol does not allow reliable interpretation of the paleoclimate. On the other hand, pollen preserved in paleosols are most probably local in origin, and so even a small amount of pollen can reveal the paleoenvironment fairly well. The few identified pollen, including possible Corylus grains, as well as, the cell tissue, however, imply that the climate was fairly temperate and coniferous or mixed-tree forests were growing at the site.

Although there are some uncertainties with the OSL datings, the results herein raise a question of a possible Early Weichselian glaciation and deglaciation in westernmost Finland. The extent of the Early Weichselian glaciations is still questionable (e.g. Lundqvist, 1991; Robertsson et al., 1997; 2005; Siegert et al., 2001). Western Finland is the key area in this respect, as it is close to the center of the Scandinavian glaciations. The possible Early Weichselian glaciation(s), however, would mean that the Early Weichselian interstadials, Brørup and Odderade (or at least the other of them), were longer and more temperate and humid than previously reported. Evidently, this topic requires further investigation.

The two new formal names used in Fig. 4, the Kodesjärvi Formation (unit 4) and the Isojoki Sand (unit 7), are proposed to be included to the Suupohja Group, which comprise all the Pleistocene deposits in the Suupohja region (Pitkäranta, 2005).

\section{Conclusions}

The asymmetrical form, structures and eastward dipping layers imply that the Penttilänkangas ridge was 
deposited predominantly as coalescing subaquatic fans at the border of a westerly or northwesterly retreating glacier. This presumably took place during the final retreat of the Saalian glacier, in the marine isotope stage (MIS) 6. The ridge has been reworked and covered during later geological events, including deep water, littoral, eolian and glacial episodes. Thus, considering the Late Weichselian and Early Holocene events, two cycles of glacial melting and land emergence to littoral and subaerial conditions can be distinguished at Penttilänkangas, separated by one glacier advance between the cycles. A long ice-free episode before the latest glaciation, both temperate and cold, is indicated by the wellpreserved podzol soil profile and permafrost structures.

The analysed physical properties of the buried podzol soil show a higher maturity of podzolisation than the Holocene podzol soil in the same area. Although uncertainties exist in interpretation of age and paleoenvironment based on physical properties of single soil profiles, those determined in this study indicate that the podzolisation of the buried soil has taken at least as long time as, and/or under a slightly more temperate and humid climate than the formation of the Holocene soil.

It is estimated that a minimum of $15-20 \mathrm{ka}$ was required for the development of the podzol soil, growth of the permafrost, and cracking of the icewedges. Considering possible cool and/or dry episodes with no permafrost growth and minor podzol formation, the ice-free event has possibly been considerbly longer. It is suggested that the soil formation initiated in the Eemian Interglacial Stage (MIS 5e), and probably continued in the temperate phases of the Early Weichselian Substage (MIS 5c and 5a). Also the youngest of the Early Weichselian interstadials (MIS 5a, Odderade) was warm and humid enough that coniferous forest could grow in western Finland. According to the OSL datings, the Middle Weichselian glaciation reached western Finland 10-15 ka lat- er than usually reported, about 65-60 thousand years ago at the earliest.

Although the observations herein support the interpretation that there was a long ice-free period from the retreat of the Saalian glaciation until the advance of the first Weichselian ice-sheet during the Middle Weichselian Substage, the OSL results contradict with this. If the OSL-datings are correct (within the error limits), that would lead to the conclusion that an Early Weichselian glaciation (MIS 5b?) covered westernmost Finland. In that case, all the studied deposits should have been deposited after the Eemian Interglacial, and the Early Weichselian ice-free stage (MIS 5c?) should have been more humid, temperate and longer than previously proposed.

The well-preserved paleosols, ice-wedge casts and cryoturbation features indicate that the Weichselian glacial erosion was locally only a few tens of centimeters deep, if significant at all, even on elevated terrains in western Finland.

\section{Acknowledgements}

Financial support was achieved from the South Ostrobothnian Fund of the Finnish Culture Foundation (grant Nr 1142), the Sohlberg Delegation of the Finnish Society of Science and Letters (grant $\mathrm{Nr}$ 516/748), the K.H. Renlund Foundation and Sito Ltd. J. Aalto prepared and analysed the pollen slides, and $\mathrm{H}$. Wenho prepared the diatom slides. T. Lempiäinen determined the cell tissue. J. Mäkinen and J.P. Palmu kindly presented some of their observations at Penttilänkangas. K.O. Eskola made the OSL measurements. P. Huhta presented the GPR profiles of the Geological Survey of Finland. J. Woodard checked the English language. Professor M. Räsänen and Dr Thair Al-Ani, as well as, both reviewers, professors J. Lundqvist and P. Johansson, gave important and useful comments on the manuscript. I am very grateful to all the above-mentioned persons and organizations. 


\section{References}

Alalammi, P. (ed.), 1987. Atlas of Finland, Folio 131: Climate. National Board of Survey and Geographical Society of Finland.

Auri, J. \& Räsänen, M., 2006. Early Weichselian interstadial lake deposits at Björkö Island, Kvarken Archipelago, Finland. In: Peltonen, P. \& Pasanen, A. (eds.) The $27^{\text {th }}$ Nordic Geological Winter Meeting, January 9-12, 2006, Oulu, Finland, abstract volume. Bulletin of the Geological Society of Finland, Special issue 1, 11.

Auri, J., Räsänen, M., Klap, A., Huitti, J., Nenonen, K. \& Breilin, O., 2006. A continuous Early Weichselian lake record covering Brörup and Odderade interstadials at Björkö Island, Ostrobothnia coast, western Finland. In: Johansson, P., Lunkka, J.-P. \& Sarala, P. (eds.) Late Pleistocene glacigenic deposits in the central part of the Scandinavian ice sheet, the INQUA Peribaltic Group Field Symposium in Finland, September 11-15, 2006, abstracts. Geological Survey of Finland, Rovaniemi, p. 6.

Balescu, S., Lamothe, M, \& Lautridou, J.-P., 1997. Luminescence evidence for two Middle Pleistocene interglacial events at Tourville, northern France. Boreas 26, 61-72.

Battarbee, R.W., Jones, V.J., Flower, R.J., Cameron, N.G., Bennion, H., Carvalho, L. \& Juggins, S., 2001. Diatoms. In: Smol, J.P., Birks, H.J.B. \& Last, W.M. (eds.) Tracking Environmental Change Using Lake Sediments, Volume 3: Terrestrial, Algal, and Siliceous Indicators. Kluwer Academic Publishers, Dordrecht, pp. 155-202.

Benn, D.I. \& Evans, D.J.A., 1996. The interpretation and classification of subglacially derived sediments. Quaternary Science Reviews 15, 23-52.

Benn, D.I. \& Evans, D.J.A., 1998. Gaciers \& Glaciation. Arnold, London, 733 p.

Bennet, K.D. \& Willis, K.J., 2001. Pollen. In: Smol, J.P., Birks, H.J.B. \& Last, W.M. (eds.) Tracking Environmental Change Using Lake Sediments, Vol. 3: Terrestrial, Algal, and Siliceous Indicators. Kluwer Academic Publishers, Dordrecht, pp. 5-32.

Birkeland, P.W., 1978. Soil development as an indication of relative age of Quaternary deposits, Baffin Island, N.W.T., Canada. Arctic and Alpine Research 10, 733-747.

Birkeland, B.W., 1984. Holocene soil chronofunctions, southern Alps, New Zealand. Geoderma 34, 115-134.

Björk, S. \& Wohlfarth, B., 2001. ${ }^{14} \mathrm{C}$ Chronostratigraphic techniques in paleolimnology. In: Last, W.M. \& Smol, J.P. (eds.) Tracking Environmental Change Using Lake Sediments. Volume 1: Basin Analysis, Coring, and Chronological Techniques. Kluwer Academic Publishers, Dordrecht, pp. 205-245.

Björnbom, S., 1979. Clayey basal till in central and northern Sweden. A deposit from an old phase of the Würm glaciation. Sveriges Geologiska Undersökning C573, 1-62.

Black, R.F., 1976. Periglacial Features Indicative of Per- mafrost: Ice and Soil Wedges. Quaternary Research 6, 3-26.

Boardman, J., 1985. Comparison of Soils in Midwestern United States and Western Europe with the Interglacial Record. Quaternary Research 23, 62-75.

Bockheim, J.G., 1979. Properties and relative age of soils of south-western Cumberland Peninsula, Baffin Island, N.W.T., Canada. Arctic and Alpine Research 11, 289-306.

Bockheim, J.G., 1980. Solution and use of chronofunctions in studying soil development. Geoderma 24, 71-85.

Bouchard, M.A., Gibbard, P. \& Salonen, V.-P., 1990. Lithostratotypes for Weichselian and pre-Weichselian sediments in southern and western Finland. Bulletin of the Geological Society of Finland 62, 79-95.

Bøtter-Jensen, L. \& Duller, G.A.T., 1992. A new system for measuring OSL from quartz samples. Nuclear Tracks Radiation Measurements 20, 549-553.

Bøtter-Jensen, L., Mejdahl, V. \& Murray, A.S., 1999. New light on OSL. Quaternary Science Reviews 18, 303-309.

Cajander, A.K., 1949. Metsätyypit ja niiden merkitys. English summary: Forest types and their signifigance. Acta Forestalia Fennica 56, 1-71.

Catt, J.A., 1990. Paleopedology manual. Quaternary International $6,1-95$.

Catt, J.A., 1991. Soils as indicators of Quaternary climatic change in mid-latitude regions. Geoderma 51, $167-187$.

Chappel, J. \& Shackleton, N.J., 1986. Oxygen isotopes and sea level. Nature 324, 137-140.

Davis, J.L. \& Annan, A.P., 1989. Ground-penetrating radar for high resolution mapping of soil and rock stratigraphy. Geophysical Prospecting 37, 531-551.

Dearing, J.A., Hay, K.L. Baban, M.J., Huddleston, A.S., Wellington, E.M.J. \& Loweland, P. J., 1996. Magnetic susceptibility of soil; an evaluation of conflicting theories using a national data set. Geophysical Journal International $127,728-734$.

Delisle, G., 1998. Numerical simulation of permafrost growth and decay. Journal of Quaternary Science 13, 325-333.

Donner, J., 1988. The Eemian site of Norinkylä compared with other interglacial and interstadial sites in Ostrobothnia, western Finland. Annales Acadamicae Scientiarum Fennicae A III 149, 1-31.

Donner, J., 1995. The Quaternary History of Scandinavia. World and Regional Geology 7. Cambridge University Press, Cambridge, 200 p.

Eyles, N. \& Eyles, C.H., 1992. Glacial Depositional Systems. In: Walker, R.G. \& James, N.P. (eds.) Facies Models. Response to sea level change. Geological Association of Canada, St. John's, Newfoundland, pp. 73-100.

Follmer, L.R., 1998. A scale for judging degree of soil and paleosol development. Quaternary International 51/52, $12-13$. 
Fuchs, M. \& Owen, L.A., 2008. Luminescence dating of glacial and associated sediments: review, recommendations and future directions. Boreas 37, 636-659.

Fyfe, G., 1990. The effect of water depth on ice-proximal glaciolacustrine sedimentation: Salpausselkä I, southern Finland. Boreas 19, 147-164.

Gibbard, P., Forman, S., Salomaa, R., Alhonen, P., Jungner, H., Peglar, S., Suksi, J. \& Vuorinen, A., 1989. Late Pleistocene stratigraphy at Harrinkangas, Kauhajoki, western Finland. Annales Academiae Scientiarum Fennicae A III 150, 1-36.

Gilbert, R., Desloges, J.R \& Clague, J.J., 1997. The glacilacustrine sedimentary environment of Bowser Lake in northern Coast Mountains of British Columbia, Canada. Journal of Paleolimnology 17, 331-346.

Glückert, G., Rantala, P. \& Ristaniemi, O., 1993. Itämeren jääkauden jälkeinen rannansiirtyminen Pohjanmaalla. English summary: Postglacial shore-level displacement of the Baltic in Ostrobothnia. Publications of the Department of Quaternary Geology, University of Turku 77, 1-36.

Godfrey-Smith, D.I., Huntley, D.J. \& Chen, W.H., 1988. Optical dating studies of quartz and feldspar sediment extracts. Quaternary Science Reviews 7, 373-380.

Grimley, D.A., Nancy, K. \& Bramstedt, M.W., 2004. Using magnetic susceptibility to facilitate more rapid, reproducible and precise delineation of hydric soils in the midwestern USA. Catena 58, 183-213.

Harry, D.G. \& Gozdzik, J.S., 1988. Ice wedges: growth, thaw transformation, and palaeoenvironmental signifigance. Journal of Quaternary Science 3, 39-55.

Havinga, A.J., 1967. Palynology and pollen preservation. Review of Palaeobotany and Palynology 2, 81-98.

Holmlund, P. \& Fastook, J., 1995. A time dependent glaciological model of the Weichselian ice sheet. Quaternary International 27, 53-58.

Houmark-Nielsen, M., 2008. Testing OSL failures against a regional Weichselian glaciation chronology from southern Scandinavia. Boreas 37, 660-677.

Huijzer, B. \& Vandenberghe, J., 1998. Climatic reconstruction of the Weichselian Pleniglacial in northwestern and central Europe. Journal of Quaternary Science 13, 391-417.

Hütt, G., Jungner, H., Kujansuu, R. \& Saarnisto, M., 1993. OSL- and TL-dating of buried podzol and overlying sands in Ostrobothnia, western Finland. Journal of Quaternary Science 8, 125-132.

Jauhiainen, E., 1973. Age and degree of podzolisation of sand soils on the coastal plain of northwest Finland. Commentationes Biologicae 68, 1-32.

Jenny, H., 1941. Factors on Soil Formation. McGRaw-Hill, New York, 281 p.

Karlström, E.T. \& Osborn, G., 1992. Genesis of Buried Paleosols and Soils in Holocene and Late Pleistocene Tills, Bugaboo Glacier Area, British Columbia, Canada. Arctic and Alpine Research 24, 108-123.
Kejonen, A., 1997. Permafrost and patterned grounds in Finland - periglacial or something else. Bulletin of the Geological Society of Finland 69, 97-108.

Kemp, R., 1985. The cause of redness in some buried and non-buried soils in eastern England. Journal of Soil Science 36, 329-334.

Kjær, K.H., Lagerlund, E., Adrielsson, L., Puthusserry, J.T., Murray, A. \& Sandgren, P., 2006. The first independent chronology for Middle and Late Weichselian sediments from southern Sweden and the Island of Bornholm. GFF 128, 209-220.

Kleman, J., Hättestrand, C., Borgström, I. \& Stroeven, A., 1997. Fennoscandian paleoglaciology reconstructed using glacial geological inversion method. Journal of Glaciology 43, 283-299.

Kleman, J., Stroeven, A. \& Lundqvist, J., 2008. Patterns of Quaternary ice sheet erosion and deposition in Fennoscandia and a theoretical framework for explanation. Geomorphology 97, 73-90.

Korsman, K., Koistinen, T., Kohonen, J., Wennerström, M., Ekdahl, E., Honkamo, M., Idman, H. \& Pekkala, Y. (eds.), 1997. Bedrock map of Finland 1:1000 000. Geological Survey of Finland, Espoo.

Kotilainen, M., 2004. Dune stratigraphy as an indicator of Holocene Climatic Change and Human Impact in Northern Lapland, Finland. Annales Academiae Scientiarum Fennicae, Geologica-Geographica 166, 1-156.

Kujansuu, R., 1992. Paleosols as Quaternary stratigraphical key horizons in Ostrobothnia, western Finland. Bulletin of the Geological Society of Finland 64, 161-167.

Kujansuu, R., Saarnisto, M., Räisänen, M.-L. \& Hansel, A., 1991. Fossil soil of Kärjenkoski and its correlatives in Ostrobothnia, western Finland. In: Autio S. (ed.) Geological Survey of Finland, Current Research 1989-1990. Geological Survey of Finland, Special Paper 12, 119-126.

Leffingwell, E. de K., 1915. Ground-ice wedges; the dominant form of ground-ice on the north coast of Alaska. Journal of Geology 23, 635-654.

Lehtonen, M.I., Kujala, H., Lehtonen, A., Mäkitie, H. \& Virransalo, P., 2004. Etelä-Pohjanmaan liuskealueen kallioperä - Bedrock Map of the Southern Ostrobothnia. Geological Survey of Finland, Espoo.

Lundqvist, J., 1973. Dark bluish boulder-clay: a possible deposit from the first Würm glaciation. Bulletin of the Geological institutions of the University of Uppsala, New Series 5, 19-20.

Lundqvist, J., 1991. Some Problems of the Weichselian in Central Scandinavia. In: Andersen, B.G. \& Königsson, L.-K. (eds.) Late Quaternary stratigraphy in the Nordic Countries 150000 - 15000 B.P. Striae 34, 95-98.

Lundström, U.S., van Breemen, N. \& Bain, D., 2000. The podzolisation process. A review. Geoderma 94, 91-107.

Lunkka, J.-P. \& Alhonen, P., 1996. The development of a late Weichselian - early Holocene subaqueous ice-con- 
tact fan, Teikangas, SW Finland. Bulletin of the Geological Society of Finland 68, 34-49.

Lunkka, J. P. \& Gibbard, P., 1996. Ice-marginal sedimentation and its implication for ice-lobe deglaciation patterns in the Baltic region: Pohjankangas, western Finland. Journal of Quaternary Science 11, 377-388.

Lunkka, J.-P., Murray, A. \& Korpela, K., 2008. Wechselian sediment succession at Ruunaa, Finland, indicating a Mid-Weichselian ice-free interval in eastern Fennoscandia. Boreas 37, 234-244.

Lønne, I., 1995. Sedimentary facies and depositional architecture of ice-contact glaciomarine systems. Sedimenatary Geology 98, 13-43.

Maack, A., 1967. Fossil ice-wedge polygons in the Kunes and Båtsfjord areas. Lund Studies in Geography, Series A 40, 41-67.

Mackay, J.R., 1974. Ice-wedge cracks, Garry Island, Northwest Territories. Canadian Journal of Earth Sciences 11, 1366-1383.

Mackay, J.R., 1975. The closing of ice-wedge cracks in permafrost, Garry Island, Northwest Territories. Canadian Journal of Earth Sciences 12, 1668-1674.

Mackay, J.R., 1986. The first 7 years (1978-1985) of icewedge growth, Illisarvik experimental drained lake site, western arctic coast. Canadian Journal of Earth Sciences 23, 1782-1795.

Maher, B.A., 1998. Magnetic properties of modern soils and Quaternary loessic paleosols: paleoclimatic implications. Palaeogeography, Palaeoclimatology, Palaeoecelogy 137, 25-54.

Martinson, D.G., Pisias, N.J., Hays, J.D., Imbrie, J., Moore, T.C.Jr. \& Shacleton, N.J., 1987. Age dating and the orbital theory of Ice Ages: Development of a high resolution 0 to 300 000-year chronostratigraphy. Quaternary Research 27, 1-29.

Massari, F. \& Parea, G.C., 1988. Progradational gravel beach sequences in a moderate- to high-energy, microtidal marine environment. Sedimentology 35, 881-913.

Mokma, D.L., Yli-Halla, M. \& Lindqvist, K., 2004. Podzol formation in sandy soils of Finland. Geoderma 120, 259-272.

Mullins, C.E., 1977. Magnetic susceptibility of the soil and its significance in soil science - a review. Journal of Soil Science 28, 223-246.

Murray, A.S. \& Olley, J.M., 2002. Precision and accuracy in the optically stimulated luminescence dating of sedimentary quartz: a status review. Geochronometria 21, 1-16.

Murray, A.S. \& Wintle, A.G., 2000. Luminescence dating of quartz using an improved single-aliquot protocol. Radiation measurements 32, 57-73.

Mäkinen, J. \& Räsänen, M., 2003. Early Holocene regressive spit-platform and nearshore sedimentation on a glaciofluvial complex during the Yoldia Sea and the Ancylus Lake phases of the Baltic Basin, SW Finland. Sedimentary Geology 158, 25-56.
Møller, I. \& Dennis, A., 2003. A GPR study of sedimentary structures within a transgressive coastal barrier along the Danish North Sea Coast. In: Bristow, C.S. \& Jol, H.M. (eds.) Ground Penetrating Radar in sediments. Geological Society, London. Special Publications 211, 55-65.

Neal, A., 2004. Ground-penetrating radar and its use in sedimentology: principles, problems and progress. EarthScience Reviews 66, 261-330.

Nenonen, K., 1995. Pleistocene stratigraphy and reference sections in southern and western Finland. Geological Survey of Finland, Regional Office for Mid-Finland, $94 \mathrm{p}$.

Nielsen, L.H., Johannessen, P.N. \& Surlyk, F., 1988. A Late Pleistocene coarse-grained spit-platform sequence in northern Jylland, Denmark. Sedimentology 35, 915937.

Niemelä, J. \& Jungner, H., 1991. Thermoluminescence dating of late Pleistocene sediments related to till-covered eskers from Ostrobothnia, Finland. In: Autio, S. (ed.) Geological Survey of Finland, Current Research 1989-1990. Geological Survey of Finland, Special Paper $12,135-138$

Niemelä, J. \& Tynni, R., 1979. Interglacial and interstadial sediments in the Pohjanmaa region, Finland. Geological Survey of Finland, Bulletin 302, 1-48.

North American Commission on Stratigraphic Nomenclature, 1982. North American stratigraphic code. Bulletin of the American Association of Petroleum Geologists $67,841-875$.

Novak, P. \& Pedersen, G.K., 2000. Sedimentology, seismic facies and stratigraphy of a Holocene spit-platform complex interpreted from high-resolution shallow seismics, Lysegrund, southern Kattegat, Denmark. Marine Geology 162, 317-335.

Ó Cofaigh, C. \& Dowdeswell, J.A., 2001. Laminated sediments in glacimarine environments: diagnostic criteria for their interpretation. Quaternary Science Reviews 20, 1411-1436.

Olsen, L., 1998. Pleistocene paleosols in Norway: implications of past climate and glacial erosion. Catena 34, 75-103.

Olson, C.G. \& Nettleton, W.D., 1998. Paleosols and the effects of alteration. Quaternary International 51/52, $185-194$.

Olsson, I.U., 1986. Radiometric dating. In: Berglund, B.E. (ed.) Handbook of Holocene Palaeoecology and Palaeohydrology. John Wiley \& Sons Ltd, Chichester, pp. 273-312.

Palmer, D., 1986. Refraction seismics. Handbook of geophysical exploration; Section I: Seismic exploration. Geophysical Press, London, 269 p.

Petäjä-Ronkainen, A., Peuraniemi, V. \& Aario, R., 1992. On podzolisation in glaciofluvial material in Northern Finland. Annales Academiae Scientiarum Fennicae A III 156, 1-19. 
Péwé, T., 1966. Paleoclimatic significance of fossil ice-wedges. Biuletin Peryglacjalny 15, 66-73.

Pitkäranta, R., 2005. A proposal for formal lithostratigraphical names in the Suupohja region, western Finland. In: Ojala, A.E.K. (ed.) Quaternary studies in the northern and Arctic regions of Finland. Geological Survey of Finland, Special Paper 40, 91-95.

Pitkäranta, R, 2009. Lithostratigraphy and age estimations of the Pleistocene erosional remnants near the centre of the Scandinavian glaciations in western Finland. Quaternary Science Reviews 28, 166-180.

Punkari, M., 1997. Subglacial processes of the Scandinavian Ice Sheet in Fennoscandia inferred from flow-parallel features and lithostratigraphy. Sedimentary Geology $111,263-283$.

Rainio, H. \& Lahermo, P., 1976. Observations on dark grey basal till in Finland. Bulletin of the Geological Society of Finland 48, 137-152.

Rainio, H. \& Lahermo, P., 1984. New aspects on the distribution and origin of the so called dark till. Striae 20, 45-47.

Retallack, G.J., 1986. The fossil record of soils. In: Wright, V.P. (ed.) Paleosols, their recognition and interpretation. Princeton University Press, Princeton, New Jersey, 1-57.

Reuter, G., 2000. A logical system of paleopedological terms. Catena 41, 93-109.

Ruellan, A., 1971. The history of soils: some problems of definition and interpretation. In: Yaalon, D.H. (ed.) Paleopedology; origin, nature and dating of paleosols. International Society of Soil Science and Israel University Press, Jerusalem, pp. 3-13.

Ristaniemi, O., Eronen, M., Glückert, G. \& Rantala, P., 1997. Holocene and recent shoreline changes on the rapidly uplifting coast of Western Finland. Journal of Coastal Research 13, 397-406.

Robertsson, A.-M., Svedlund, J.-O., Andrén, T. \& Sundh, M., 1997. Pleistocene stratigraphy in the Dellen region, central Sweden. Boreas 26, 237-260.

Robertsson, A.-M., Lundqvist, J. \& Brunnberg, L., 2005. Dark clayey till in central and northern Sweden - microfossil content and stratigraphical importance. GFF 127, 169-178.

Saarnisto, M. \& Salonen, V.-P., 1995. Glacial history of Finland. In: Ehlers, J., Kozarski, S. \& Gibbard, P. (eds.) Glacial Deposits in North-East Europe. A.A.Balkema, Rotterdam, pp. 3-10.

Salomaa, R., 1982. Post-glacial shoreline displacement in the Lauhanvuori area, western Finland. Annales Academiae Scientiarum Fennicae AIII 134, 81-97.

Salonen, V.-P., Kaakinen, A., Kultti, S., Miettinen, A., Eskola, K.O. \& Lunkka, J.P., 2008. Middle Weichselian glacial event in the central part of the Scandinavian Ice Sheet recorded in the Hitura pit, Ostrobothnia, Finland. Boreas 37, 38-54.

Salvador, A. (ed.), 1994. International Stratigraphic Guide - a guide to stratigraphic classification, terminology, and procedure. 2nd edition. The International Union of Geological Sciences, Trondheim, and The Geological Society of America, Boulder, Colorado, 214 p.

Schaetzl, R.J. \& Isard, S.A., 1991. Distribution of Spodosol soils in southern Michican: a climatic interpretation. Annals of the Association of the American Geographers $81,425-442$.

Schaetzl, R.J. \& Isard, S.A., 1996. Regional-scale relationship between climate and strength of podzolisation in the Great Lakes Region, North America. Catena 28, 47-69.

Schwartz, R.K., 1982. Bedform and stratification characteristics of some modern small-scale washover sand bodies. Sedimentology 29, 835-849.

Schwertmann, U., Murad, E. \& Schulze, D.G., 1982. Is there Holocene reddening (hematite formation) in soils of axeric temperate areas? Geoderma 27, 209-223.

Seppälä, M., 1995. Deflation and redeposition of sand dunes in Finnish Lapland. Quaternary Science Reviews 14, 799-809.

Siegert, M.J., Dowdeswell, J.A., Hald, M. \& Svendsen, J.-I., 2001. Modelling the Eurasian Ice Sheet through a full (Weichselian) glacial cycle. Global and Planetary Change 31, 367-385.

Sjögren, B., 1984. Shallow Refraction Seismics. Chapman and Hall, London, 268 p.

Smith, D.G. \& Jol, H.M., 1992. GPR results used to infer depositional processes of coastal spits in large lakes. In: Hänninen, P. \& Autio, S. (eds) Fourth International Conference on Ground Penetrating Radar, June 8-13, Rovaniemi. Geological Survey of Finland, Special Paper 16, 169-177.

Smith, D.G., Simpson, C.J., Jol, H.M., Meyers, R.A. \& Currey, D.R., 2003. GPR stratigraphy used to infer transgressive deposition of spits and a barrier, Lake Bonneville, Stocton, Utah, USA. In: Bristow, C.S. \& Jol, H.M. (eds) Ground Penetrating Radar in sediments. Geological Society, London. Special Publications 211, 79-86.

Starr, M.R., 1991. Soil formation and fertility along a 5000 year chronosequence. In: Pulkkinen (ed.) Environmental geochemistry in northern Europe. Geological Survey of Finland, Special Paper 9, 99-104.

Svensson, H., 1988. Ice-wedge casts and relict polygonal patterns in Scandinavia. Journal of Quaternary Science 3, 57-67.

Tarnocai, C. \& Valentine, K.W.G., 1989. Relict properties of soils of the arctic and subarctic regions of Canada. Catena Supplement 16, 9-39.

Tedrow, J.C., 1977. Soils of the Polar Landscapes. Rutgers University Press, New Brunswick, 638 p.

Thompson, R.\& Morton, D.J., 1979. Magnetic susceptibility and particle size distribution in recent sediments of the Loch Lomond Drainage Basin, Scotland. Journal of Sedimentary Petrology 49, 801-812.

Van der Meer, J.J.M., Kjær, K.H., Krüger, J., Rabassa, J. \& 
Kilfeather, A.A., 2009. Under pressure: clastic dykes in glacial settings. Quaternary Science Reviews 28, 708720.

Van Vliet-Lanoë, B., 1988. The significance of cryoturbation phenomena in environmental reconstruction. Journal of Quaternary Science 3, 85-96.
Williams, M., 1992. Evidence for the dissolution of magnetite in recent Scottish peats. Quaternary Research 37, 171-182.

Williams, R.D. \& Cooper, J.R., 1990. Locating soil boundaries using magnetic susceptibility. Soil Science 150, 889-895. 